Energy and Transportation Science Division

\title{
Joint China-United States Report for Year 1 Insulation Materials and Systems Project Area Clean Energy Research Center - Building Energy Efficiency (CERC-BEE) \\ Review of Standards and Codes Pertinent to Building Practices and Wall Insulation Systems
}

Date published: August, 2012

Therese Stovall and Kaushik Biswas, Oak Ridge National Laboratory Song Bo and Sissi Zhang, China Academy of Building Research

Prepared by

OAK RIDGE NATIONAL LABORATORY

Oak Ridge, Tennessee 37831-6283

managed by

UT-BATTELLE, LLC

for the

U.S. DEPARTMENT OF ENERGY

under contract DE-AC05-00OR227 


\title{
DOCUMENT AVAILABILITY
}

Reports produced after January 1, 1996, are generally available free via the U.S. Department of Energy (DOE) Information Bridge.

Web site http://www.osti.gov/bridge

Reports produced before January 1, 1996, may be purchased by members of the public from the following source.

\author{
National Technical Information Service \\ 5285 Port Royal Road \\ Springfield, VA 22161 \\ Telephone 703-605-6000 (1-800-553-6847) \\ TDD 703-487-4639 \\ Fax 703-605-6900 \\ E-mail info@ntis.gov \\ Web site http://www.ntis.gov/support/ordernowabout.htm
}

Reports are available to DOE employees, DOE contractors, Energy Technology Data Exchange (ETDE) representatives, and International Nuclear Information System (INIS) representatives from the following source.

Office of Scientific and Technical Information

P.O. Box 62

Oak Ridge, TN 37831

Telephone 865-576-8401

Fax 865-576-5728

E-mail reports@osti.gov

Web site http://www.osti.gov/contact.html

This report was prepared as an account of work sponsored by an agency of the United States Government. Neither the United States Government nor any agency thereof, nor any of their employees, makes any warranty, express or implied, or assumes any legal liability or responsibility for the accuracy, completeness, or usefulness of any information, apparatus, product, or process disclosed, or represents that its use would not infringe privately owned rights. Reference herein to any specific commercial product, process, or service by trade name, trademark, manufacturer, or otherwise, does not necessarily constitute or imply its endorsement, recommendation, or favoring by the United States Government or any agency thereof. The views and opinions of authors expressed herein do not necessarily state or reflect those of the United States Government or any agency thereof. 


\section{Contents}

1. Introduction 4

2. Building Codes 5

2.1 History of Building Code Advances 5

2.2 Data Sources for Building Codes 6

2.3 Comparison of Building Codes Based upon Climate 8

3. Wall Insulation Systems $\quad 12$

3.1 History of Advances in Wall Insulation Systems 12

3.1.1 Europe and the U.S.

3.1.2 China 15

3.2 Data Sources for Wall Insulation System Standards 17

3.3 Comparison of Wall Insulation System Standards 18

3.3.1 Comparing EOTA ETAG-004 (2008) to JGJ144-2008 18

3.3.1 Comparing BS EN 13499-2003 with JG149-2003 23

4. Building Stock 27

4.1 Data Sources for U.S. Buildings

4.1 Data Sources for China Buildings 28

4.2 Weatherization and Retrofit Activities in the U.S. 28

5. Fire Safety codes 30

References $\quad 32$

Appendix A: Nomenclature $\quad 34$

Appendix B: CERC Program Visitor Report, June 6-7, 2012

Appendix C: Commonly Used Materials in Chinese External Wall Insulation 41

Appendix D: U.S. Retrofit Case Studies $\quad 42$ 


\section{INTRODUCTION}

In November of 2009, the presidents of China and the U.S. announced the establishment of the Clean Energy Research Center (CERC). This broad research effort is co-funded by both countries and involves a large number of research centers and universities in both countries. One part of this program is focused on improving the energy efficiency of buildings. The vision of the Clean Energy Research Center - Building Energy Efficiency (CERC-BEE) is

To build a foundation of knowledge, technologies, tools, human

capabilities, and relationships that position the United States and China for a future with very low energy buildings resulting in very low $\mathrm{CO}_{2}$ emissions

One portion of the CERC-BEE was focused on building insulation systems. The research objective of this effort was to

Identify and investigate candidate high performance fire resistant building insulation technologies that meet the goal of building code compliance for exterior wall applications in green buildings in multiple climate zones.

A Joint Work Plan was established between researchers at the China Academy of Building Research and Oak Ridge National Laboratory. Efforts in the first year under this plan focused on information gathering. As described in the Joint Work Plan,

The objective of this research program is to reduce building energy use in China via improved building insulation technology. In cold regions in China, residents often use inefficient heating systems to provide a minimal comfort level within inefficient buildings. In warmer regions, air conditioning has not been commonly used. As living standards rise, energy consumption in these regions will increase dramatically unless significant improvements are made in building energy performance. Previous efforts that defined the current state of the built environment in China and in the U.S. will be used in this research.

In countries around the world, building improvements have typically followed the implementation of more stringent building codes. There have been several changes in building codes in both the U.S. and China within the last few years. New U.S. building codes have increased the amount of wall insulation required in new buildings. New government statements from multiple agencies in China have recently changed the requirements for buildings in terms of energy efficiency and fire safety. A related issue is the degree to which new standards are adopted and enforced. In the U.S., standards are developed using a consensus process, and local government agencies are free to implement these standards or to ignore them. For example, some U.S. states are still using 2003 versions of the building efficiency standards. There is also a great variation in the degree to which the locally adopted standards are enforced in different U.S. cities and states. With a more central process in China, these issues are different, but possible impacts of variable enforcement efficacy may also exist. Therefore, 
current building codes in China will be compared to the current state of building fire-safety and energy-efficiency codes in the U.S. and areas for possible improvements in both countries will be explored.

In particular, the focus of the applications in China will be on green buildings. The terminology of 'green buildings' has different meanings to different audiences. The U.S. research is interested in both new, green buildings, and on retrofitting existing inefficient buildings. An initial effort will be made to clarify the scope of the pertinent wall insulation systems for these applications.

Although this work will not be continued into future CERC program activities, this report was prepared to document the results of the initial efforts. To aid the reader, acronyms and other nomenclature are defined in Appendix A. The last meeting between the China and U.S. researchers is described in Appendix B.

\section{BUILDING CODES}

\subsection{History of Building Code Advances}

Following the global energy crisis of the 1970s, governments around the world performed comprehensive and realistic energy consumption analysis. Industrial projects and transportation energy-saving measures are usually accompanied by huge investment and economic costs. Building conservation measures offered the lowest cost, so energy conservation programs placed an emphasis on reducing building energy consumption. A consensus developed on the need for energy efficiency standards and regulations for building design. Over the following years, many countries set up independent building energy efficiency standards.

The highest energy-saving methods were promoted first in Central Europe (Germany, Austria, Switzerland) and Scandinavia (Sweden, Norway, Denmark) in order to achieve the most effective social integration. For example, Germany increased the annual building energy efficiency design requirements four times between 1977 and 2002:

- Pre-1977 - $350 \mathrm{kWh} / \mathrm{m}^{2}$

- $1997-200 \mathrm{kWh} / \mathrm{m}^{2}$

- $1984-150 \mathrm{kWh} / \mathrm{m}^{2}$

- $1995-100 \mathrm{kWh} / \mathrm{m}^{2}$

- $2002-70 \mathrm{kWh} / \mathrm{m}^{2}$

- Future targets - a passive house using less than $15 \mathrm{kWh} / \mathrm{m}^{2}$.

In the U.S., a series of building energy efficiency standards began in 1975, when ASHRAE (American Society of Heating, Refrigerating and Air-Conditioning Engineers) issued standard 90.1 describing the energy-efficient design of new commercial buildings. (Standard 90.2 for residential buildings was not issued until 1993 and has not been as widely accepted.) The ASHRAE standards are continuously revised, with new versions published every third year. Before 2010, the ASHRAE 90.1 standard focused on the mechanical structure and fixtures in the building; more current versions also address the operation and maintenance of the building and the use of renewable resources.

Multiple organizations worked together to develop the 1997 Model Code for Energy Conservation (MEC). Upon the formation of the Internation Code Council (ICC), the Model Code was transitioned into the International Energy Conservation Code (IECC), which addresses 
both residential and commercial buildings and is also revised on a frequent basis. In the U.S., individual states select their own building standards; ten states have no statewide code. To encourage broader adoption, a major revision was made to the IECC code in 2006 to simplify the requirements. Subsequent revisions have focussed on improving the energy efficiency requirements. Buildings built to the 2012 IECC will use $\sim 30 \%$ less energy than those built to the 2006 code.

As early as 1979, the Japan Housing Finance Corporation promulgated residential building insulation standards, providing minimum limits for building insulation. At about the same time, some other countries also began the work of improving building energy efficiency. They imposed energy efficiency standards for new buildings and achieved great results. In some countries, whole building energy consumption dropped significantly. For example, in Denmark, the heated building area increased by $30 \%$ from 1972 to 1985 , but building energy consumption for heating (including wall energy losses) decreased by 3.18 million tons of standard coal. In California, the Title 24 Code led to electricity and natural gas energy savings to businesses and residents of $\$ 15.8$ billion from 1975 to 2003, and the state's energy efficiency requirements have increased significantly since that assessment. Thus, over 30 years, building energy efficiency regulations have provided significant social and economic benefits.

\subsection{Data Sources for Building Codes}

Evans et al. (4) compared the energy codes in seven countries that were part of the AsiaPacific Partnership on Clean Development and Climate (APP). This report summarized the requirements of the building energy codes and their implementation. Individual reports for U.S., China and other countries were also published $(5,6)$. The U.S. country report by Halverson et al. focused on ASHRAE 90.1-2007 and the IECC 2006 for commercial buildings and the IECC 2006 (Low-Rise Residential buildings) for the residential sector, and presented the state-wise compliance status of the codes across the U.S.(5) Halverson et al. also briefly described the adoption, implementation and enforcement of the energy codes, which fall under the state and local jurisdictions in the U.S.

The current versions of the primary building codes followed in the U.S. are:

- ANSI/ASHRAE/IES Standard 90.1-2010: Energy Standard for Buildings Except LowRise Residential Buildings

- International Energy Conservation Code (IECC) 2009 from the International Code Council, Inc.

ASHRAE 90.1 provides minimum energy-efficient requirements for buildings and criteria for determining compliance with the requirements. ASHRAE 90.1 applies to all buildings except single-family houses, multi-family structures of three stories or fewer above grade, manufactured houses (mobile homes or modular), or buildings that use neither electricity nor fossil fuel. The IECC code regulates minimum energy conservation requirements for new buildings, both commercial and residential. Both codes provide applicable requirements based on the climate zones for U.S. and international locations. Conover et al. (7) performed a comparison study of ASHRAE 90.1 - 2007 and IECC 2009, and listed their key differences.

The 2010 building energy codes annual report from the Building Energy Codes Program (BECP) of the U.S. Department of Energy (DOE) summarizes the improvements in estimated energy savings of the IECC 2009 and ASHRAE 90.1-2007 over previous versions of the codes 
(8). The report also lists the energy-savings changes in ASHRAE 90.1-2010 and the commercial chapter of the 2012 IECC.

In addition to ASHRAE 90.1 and IECC, several U.S. states follow their individual energy codes. Two BECP reports $(9,10)$ compared the requirements of the ASHRAE 90.1-2007 code and IECC 2009 with the commercial and residential codes in each U.S. state, and estimated the typical energy savings of updating each state's code to the 2009 IECC for residential buildings. BECP further provides the current status of code adoption and compliance measurement activities for both commercial and residential buildings in each state. This information can be found at http://www.energycodes.gov/states/. The International Code Council (11) also provides lists of the different state codes and local amendments. Reed Construction Data (12) is another online resource listing all building codes followed in the different states in the U.S.

A synthesis report from PNNL (13), summarizes the Chinese building energy standards system, which include:

- Design standards for building energy efficiency.

- Inspection standards for residential and public building energy efficiency conservation.

- Technical specifications for energy efficiency renovations.

- Evaluation standards for green buildings.

The main contents of Chinese design standards are the thermal performance of the building envelope and the energy efficiency of HVAC equipment and systems - the two factors widely believed to have the greatest influence on building energy efficiency in China (13). Following is a list of the building codes in China $(13,14)$ :

- JGJ 134-2001/2010 - Design Standard for Energy Efficiency of Residential Buildings in Hot Summer and Cold Winter Zone (HSCW)

- JGJ 132-2001 - Standard for Energy Efficiency Inspection of Heating Residential Buildings

- JGJ 129-2000 - Technical Code for Renovation of Existing Heating Residential Buildings

- JGJ 26-86/95/2010 - Design Standard for Energy Efficiency of Residential Buildings in Severe Cold and Cold Zones

- JGJ 75-2003 - Design Standard for Energy Efficiency of Residential Buildings in Hot Summer and Warm Winter Zone

- GB 50189-93 - Energy Conservation Design Standard on Building Envelope and Air Conditioning for Tourist Hotels

- GB 50189-2005 - Design Standard for Energy Efficiency in Public Buildings ${ }^{1}$

- JGJ 26-86 (Trial implementation) - Energy Conservation Design Standard for New Heating Residential Buildings

- GB50411-2007 - Code for Acceptance of Energy Efficient Building Construction

The most recent versions of the Chinese building codes require the residential and public buildings to be $50-65 \%$ more energy efficient than the buildings built in 1980s (13). The

\footnotetext{
${ }^{1}$ Note the renaming of the standard GB 50189, with the scope expanded from tourist hotels to all public buildings.
} 
synthesis report also reviewed the implementation and compliance status of the Chinese codes, and identified the need for training and information dissemination (13).

\subsection{Comparison of Building Codes Based upon Climate}

Table 1 and Figure 1 compare the prescribed U-factors in the Chinese building code for residential buildings in the severe cold and cold zone (JGJ26-95) and IECC 2009. The Chinese code lists the U-factors for cities based on the mean outdoor air temperature. ASHRAE 90.1 2010 lists the heating and cooling degree days for numerous cities in different regions and provinces of China. The heating degree days are based on $18^{\circ} \mathrm{C}\left(\mathrm{HDD} 18^{\circ} \mathrm{C}\right)$ and cooling degree days are base $10^{\circ} \mathrm{C}\left(\mathrm{CDD} 18^{\circ} \mathrm{C}\right)$.

The rationale for assigning U-values in the two codes was different, but based on the same idea of adapting the building requirements to different climates. In order to make direct comparisons, it was necessary to place the climate definitions on a common basis. Heating degree day data, available for many of the cities in China, was used for comparison purposes. Representative cities listed in standard JGJ26-95 were classified into different zones based on their heating degree days, as listed in Table $1 .{ }^{2}$ Under IECC, two U-factors are listed for walls: the first value is for frame walls and the second value is for mass walls. Mass walls are allowed to have greater U-factors for climate zones 4-6 because they provide useful heat storage that can reduce total daily energy consumption.

Table 2 and Figure 2 summarize the building envelope requirements for public buildings per the energy efficiency design standard GB 50189-2005. A previous version of this code (GB50189-93) was designated as the design standard for energy efficiency of tourist hotels. Table 2 also lists the prescriptions for commercial buildings in ASHRAE 90.1-2010 and IECC 2009. Again, representative cities were chosen for comparison based on the available HDD and CDD data.

There are overlaps between the Chinese climates zones and those defined by IECC/ASHRAE 90.1, based on the distribution of the representative cities. For example, two cities, Hailar and Huma, in the 'severe cold region A' in China fall under climate zone 8 based on the number of heating degree days, while the rest of the cities in 'severe cold region A' fall under zone 7. Therefore, the U-factors under ASHRAE and IECC in Table 2 are ranges from maximum to minimum values for the appropriate climate zones. The standard GB50189 applies to public buildings that include office buildings, commercial buildings, hotels, scientific, educational, health, communications, and transportation buildings. The requirements of the IECC and ASHRAE are for both non-residential buildings and large residential buildings (hotels, dormitories, nursing homes, etc.). ASHRAE 90.1 also provides the requirements for semi-heated buildings but those weren't used in the comparison.

GB50189 further prescribes the U-factors for suspended floors or projecting floor slabs and for walls and floors between heated and unheated spaces. GB50189 also provides a 'shading coefficient' for windows in certain climate zones, which is calculated based on the geometry of the shading panel and the window.

ASHRAE and IECC prescribe the allowable solar heat gain through fenestration. The 'solar heat gain coefficient' (SHGC) is defined as the ratio of the solar heat gain entering the

\footnotetext{
${ }^{2}$ Note that the IECC values are conversions of the I-P values listed in the code.
} 
space through the fenestration assembly to the incident solar radiation. Solar heat gain includes directly transmitted solar heat and absorbed solar radiation which is then reradiated, conducted or convected into the space.

Huang et al. (15) described the development of the building energy standard for the hotsummer-warm-winter region of China. They also summarized the differences and similarities in the hot-summer-warm-winter energy code to ASHRAE 90.1-1999 requirements. For a similar climate, the ASHRAE 90.1-1999 requirements for residential buildings are comparable for exterior walls, but nearly three times lower for the roof, as compared to the hot-summer-warmwinter standard (15). 
Table 1. Maximum allowable U-factors for residential buildings in Chinese Building Code JGJ26-95 and IECC 2009

\begin{tabular}{|c|c|c|c|c|c|}
\hline \multirow{2}{*}{$\begin{array}{l}\text { Mean } \\
\text { Outdoor } \\
\text { Temp. }\left({ }^{\circ} \mathrm{C}\right)\end{array}$} & \multirow{2}{*}{ Typical Cities } & \multirow{2}{*}{$\begin{array}{l}\text { Climate } \\
\text { Zone } \\
\text { (per } \\
\text { IECC) } \\
\end{array}$} & \multirow{2}{*}{$\begin{array}{l}\text { Building } \\
\text { Element }\end{array}$} & \multicolumn{2}{|c|}{ U-factor $\left(W / m^{2}-K\right)$} \\
\hline & & & & JGJ26-95 & IECC \\
\hline \multirow{4}{*}{$-12.1 \sim-14.5$} & \multirow{4}{*}{ Hailar, Huma. } & \multirow{4}{*}{8} & Roof/Ceiling & $0.40-0.25$ & 0.15 \\
\hline & & & Wall $^{3}$ & $0.52-0.40$ & $0.32 / 0.32$ \\
\hline & & & Window & 2.00 & 1.99 \\
\hline & & & Floor & $0.45-0.25$ & 0.16 \\
\hline \multirow{4}{*}{$-9.1 \sim-14.5$} & \multirow{4}{*}{$\begin{array}{l}\text { Anda, Fujin, Hailun, } \\
\text { Harbin, Mudanjiang, } \\
\text { Qiqihar, Yichun. }\end{array}$} & \multirow{4}{*}{7} & Roof/Ceiling & $0.50-0.25$ & 0.15 \\
\hline & & & Wall & $0.52-0.40$ & $0.32 / 0.32$ \\
\hline & & & Window & $2.50-2.00$ & 1.99 \\
\hline & & & Floor & $0.50-0.25$ & 0.16 \\
\hline \multirow{4}{*}{$-4.1 \sim-9.0$} & \multirow{4}{*}{$\begin{array}{l}\text { Changchun, Datong, } \\
\text { Jiuquan, Siping, } \\
\text { Yanji. }\end{array}$} & \multirow{4}{*}{6} & Roof/Ceiling & $0.70-0.30$ & 0.15 \\
\hline & & & Wall & $0.75-0.45$ & $0.32 / 0.34$ \\
\hline & & & Window & $3.00-2.50$ & 1.99 \\
\hline & & & Floor & $0.55-0.30$ & 0.19 \\
\hline \multirow{4}{*}{$-2.1 \sim-6.0$} & \multirow{4}{*}{$\begin{array}{l}\text { Dandong, Hami, } \\
\text { Lanzhou, Tangshan, } \\
\text { Yinchuan, Yining. }\end{array}$} & \multirow{4}{*}{5} & Roof/Ceiling & $0.70-0.40$ & 0.17 \\
\hline & & & Wall & $1.10-0.56$ & $0.32 / 0.47$ \\
\hline & & & Window & $4.70-3.00$ & 1.99 \\
\hline & & & Floor & $0.55-0.40$ & 0.19 \\
\hline \multirow{4}{*}{$2.0 \sim-1.0$} & \multirow{4}{*}{$\begin{array}{l}\text { Anyang, Dezhou, } \\
\text { Jinan, Zhengzhou. }\end{array}$} & \multirow{4}{*}{$4 C$} & Roof/Ceiling & $0.80-0.60$ & 0.17 \\
\hline & & & Wall & $1.40-0.60$ & $0.32 / 0.47$ \\
\hline & & & Window & $4.70-4.00$ & 1.99 \\
\hline & & & Floor & $0.65-0.60$ & 0.19 \\
\hline \multirow{4}{*}{$2.0 \sim-2.0$} & \multirow{4}{*}{$\begin{array}{l}\text { Baoji, Beijing, } \\
\text { Tianjin, Tianshui. }\end{array}$} & \multirow{4}{*}{4} & Roof/Ceiling & $0.80-0.60$ & 0.17 \\
\hline & & & Wall & $1.40-0.55$ & $0.47 / 0.80$ \\
\hline & & & Window & $4.70-4.00$ & 1.99 \\
\hline & & & Floor & $0.65-0.55$ & 0.27 \\
\hline
\end{tabular}

\footnotetext{
${ }^{3}$ Wall U-factors are prescribed for frame and mass walls; first value - frame wall, second value - mass wall.
} 


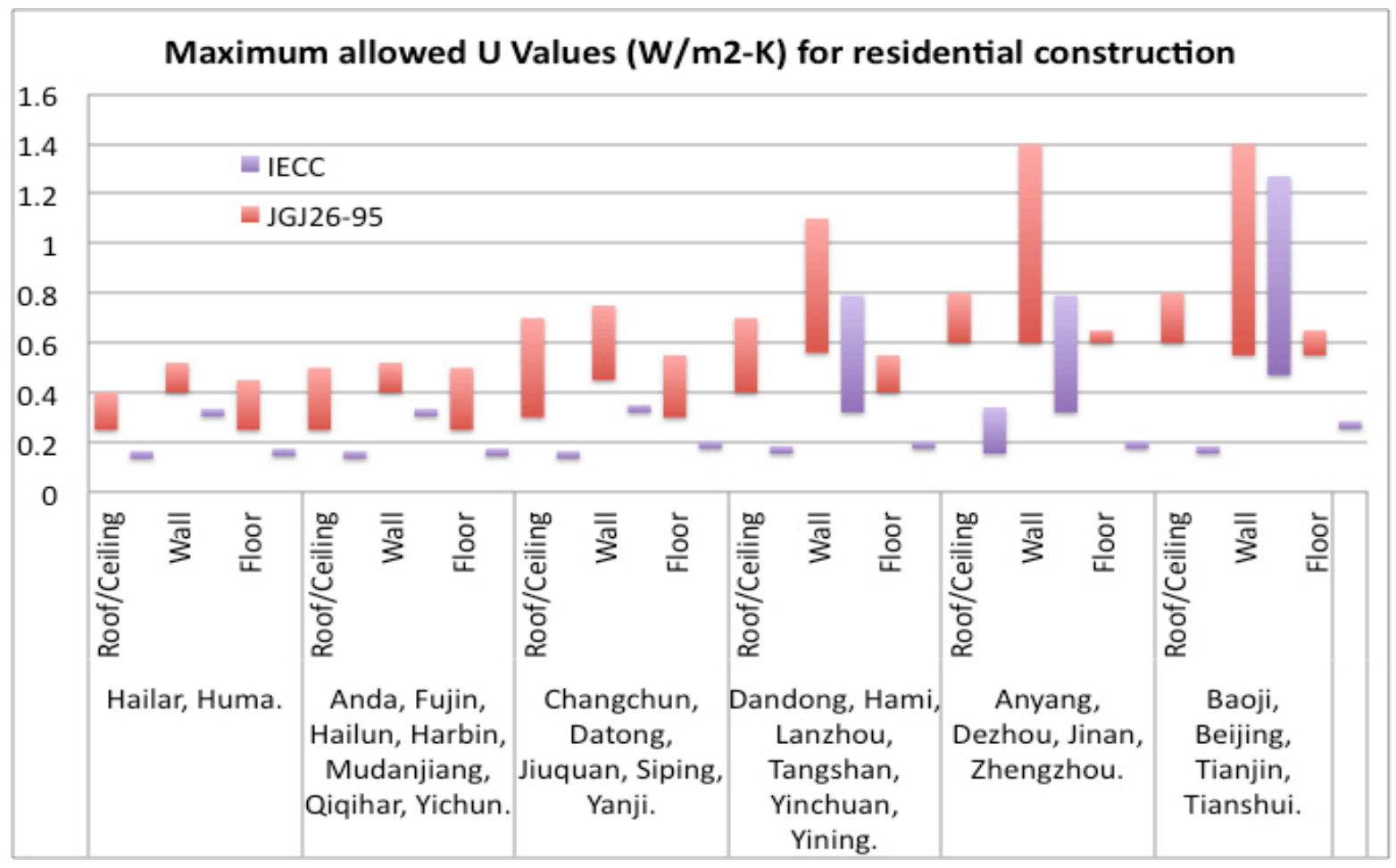

Figure 1 Comparing residential building code requirements in China and the U.S.

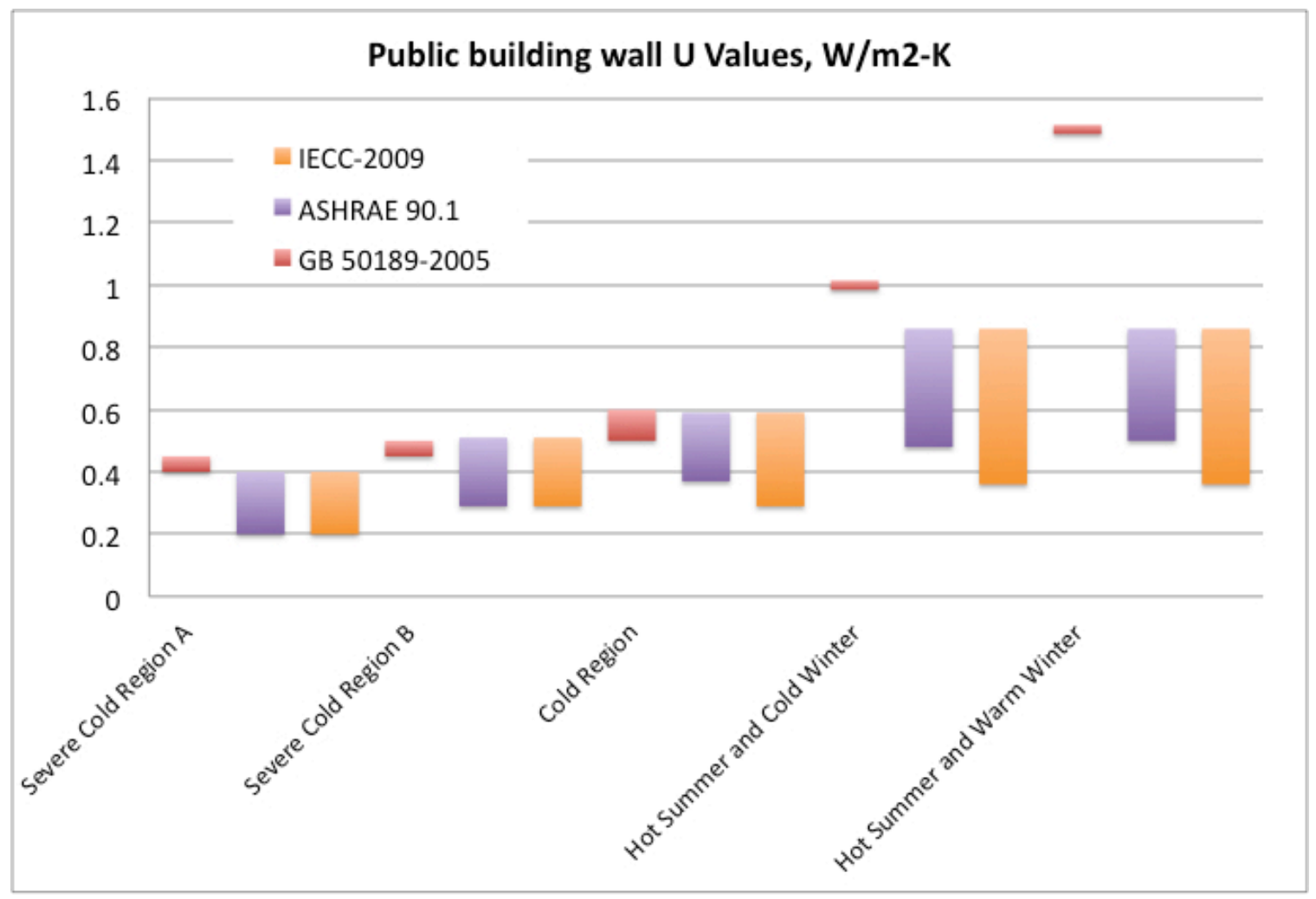

Figure 2 Comparing wall U-values for public buildings between China and U.S. building codes 
Table 2. Maximum allowable U-factors for public buildings in Chinese Building Code GB50189-2005, ASHRAE 90.1 and IECC 2009

\begin{tabular}{|c|c|c|c|c|c|}
\hline \multirow{2}{*}{$\begin{array}{l}\text { Chinese } \\
\text { Climate } \\
\text { Zone }\end{array}$} & \multirow[b]{2}{*}{$\begin{array}{l}\text { Typical Cities (IECC } \\
\text { Climate Zone) }\end{array}$} & \multirow[b]{2}{*}{$\begin{array}{l}\text { Building } \\
\text { Element }\end{array}$} & \multicolumn{3}{|c|}{ U-factor $\left(W / m^{2}-K\right)$} \\
\hline & & & GB50189 & ASHRAE & IECC \\
\hline \multirow{4}{*}{$\begin{array}{l}\text { Severe Cold } \\
\text { Region A }\end{array}$} & \multirow{4}{*}{$\begin{array}{l}\text { Hailar, Huma(IECC 8) } \\
\text { Anda, Fujin, Hailun, Harbin, } \\
\text { Mudanjiang, Qiqihar, Yichun } \\
\text { (IECC 7). }\end{array}$} & Roof & $0.35-0.30$ & $0.28-0.12$ & $0.28-0.13$ \\
\hline & & Wall & $0.45-0.40$ & $0.40-0.20$ & $0.40-0.20$ \\
\hline & & Window & $3.00-1.50$ & $4.54-1.99$ & $4.54-1.99$ \\
\hline & & Skylight & 2.50 & 6.64-3.29 & 3.41 \\
\hline \multirow{4}{*}{$\begin{array}{l}\text { Severe Cold } \\
\text { Region B }\end{array}$} & \multirow{4}{*}{$\begin{array}{l}\text { Changchun, Datong, Hohhot, } \\
\text { Jiuquan, Siping, Tongliao, } \\
\text { Urumqi, Yanji (IECC 6) } \\
\text { Dandong, Hami, Yinchuan, } \\
\text { Yining (IECC 5) }\end{array}$} & Roof & $0.45-0.35$ & $0.31-0.15$ & $0.31-0.13$ \\
\hline & & Wall & $0.50-0.45$ & $0.51-0.29$ & $0.51-0.29$ \\
\hline & & Window & $3.20-1.60$ & 4.54-1.99 & 4.54-1.99 \\
\hline & & Skylight & 2.60 & 6.64-3.29 & 3.41 \\
\hline \multirow{4}{*}{ Cold Region } & \multirow{4}{*}{$\begin{array}{l}\text { Lanzhou, Pingliang, } \\
\text { Tangshan (IECC 5) } \\
\text { Baoji, Beijing, Tianjin, } \\
\text { Tianshui (IECC 4) } \\
\text { Anyang, Dezhou, Ji'nan, } \\
\text { Zhengzhou (IECC 4C) }\end{array}$} & Roof & $0.55-0.45$ & $0.31-0.15$ & $0.31-0.13$ \\
\hline & & Wall & $0.60-0.50$ & $0.59-0.29$ & $0.59-0.29$ \\
\hline & & Window & $3.50-1.80$ & 4.83-1.99 & 4.83-1.99 \\
\hline & & Skylight & 2.70 & 7.38-3.92 & $3.69-3.41$ \\
\hline \multirow{4}{*}{$\begin{array}{l}\text { Hot Summer } \\
\text { and Cold- } \\
\text { Winter } \\
\text { Region }\end{array}$} & \multirow{2}{*}{$\begin{array}{l}\text { Ankang, Anqing, Bengbu, } \\
\text { Hefei, Nanchang, Shanghai, } \\
\text { Wuhan, Yichang, Zunyi } \\
\text { (IECC 3) }\end{array}$} & Roof & 0.70 & $0.31-0.15$ & $0.31-0.13$ \\
\hline & & Wall & 1.00 & $0.86-0.37$ & $0.86-0.36$ \\
\hline & \multirow{2}{*}{ Ganzhou (IECC 2) } & Window & $4.70-2.50$ & 6.25-3.41 & $6.25-3.41$ \\
\hline & & Skylight & 3.00 & 11.24-3.92 & $4.26-3.69$ \\
\hline \multirow{4}{*}{$\begin{array}{l}\text { Hot-Summer } \\
\text { and Warm- } \\
\text { Winter } \\
\text { Region }\end{array}$} & \multirow{4}{*}{$\begin{array}{l}\text { Beihai, Guangzhou, Hechi, } \\
\text { Liuzhou, Longyan, Nanning, } \\
\text { Shantou, Shenzhen, Xiamen } \\
\text { (IECC 2) }\end{array}$} & Roof & 0.90 & $0.31-0.15$ & $0.31-0.13$ \\
\hline & & Wall & 1.50 & $0.86-0.50$ & $0.86-0.36$ \\
\hline & & Window & $6.50-3.00$ & $6.25-3.97$ & $6.25-3.97$ \\
\hline & & Skylight & 3.50 & $11.24-7.72$ & 4.26 \\
\hline
\end{tabular}

\section{WALL INSULATION SYSTEMS}

\subsection{History of Advances in Wall Insulation Systems}

\subsubsection{Europe and the U.S.}

Exterior insulation technology originated in Europe, first in Germany and then Sweden. The initial work focused on producing an aerated concrete with lower thermal conductivity than stone 
or standard concrete. Large scale production started in 1929 and pioneers in this early work included:

- Technology development - W. Michaelis, autoclaved artificial rock process patent, 1880 ,

- Technology development - Using metal powders to generate porous concrete structure - Edison Labs patent, Jonas, W. Aylsworth and Frank L. Dyer, 1914, and

- Early adopters - In 1924, the Swedish architects Sven-Goran Eriksson and Axel Eriksson.

In the 1920's, German builders began to include light kapok board insulation in building walls. This was the first use of a system similar to today's exterior insulation finish systems. During World War II, a large number of buildings were damaged in Germany. In order to repair cracks, a layer of polystyrene or mineral wool board was pasted to the external walls of buildings. Soon after it was discovered that this approach not only helped to repair cracks, but also provided many other advantages. By providing thermal insulation, sound insulation, and moisture resistance, there was a substantial increase in living comfort. After a short time, the exterior insulation technology was started, and began to grow in the late 1960s. Exterior insulation technology rapidly developed after the world energy crisis in 1973.

Exterior insulation systems are based on either a foam insulation or a rock wool insulation. In the U.S. and Europe, foam insulation is more commonly used for low-rise buildings and rock wool is used for tall buildings. Among foam insulation products, expanded polystyrene board (EPS board) has been the most widely used in exterior wall insulation systems. (The insulation materials used as exterior insulation are described in Appendix C.) The exterior insulation system was introduced to the U.S. in 1969 and is commonly known as the Exterior Insulation Finish System, or EIFS. As light gage metal framing became more common in the 1970s and 1980 s, exterior insulation systems became much more popular, accounting for about $25 \%$ of commercial construction in the U.S. by 2007. Application of EIFS in the U.S. residential market was slow because many of the initital systems had severe moisture problems that required extensive building repairs. However, new EIFS systems incorporating a drainage plane are now available and are gaining acceptance in the US residential market. As of 2012, more than 500,000 buildings in the U.S are clad with EIFS. ${ }^{4}$

In Europe, the systems are commonly knows as External Thermal Insulation Composite Systems, or ETICS. The increasingly stringent demands of building energy efficiency standards have promoted the building energy efficiency industry in Germany, especially the exterior insulation industry. By 2007, about $40 \%$ of buildings in Germany and Switzerland were clad with ETICS. EPS is used in more than $80 \%$ of all ETICS systems in Germany. In Germany alone, the production capacity for foam insulation in 2008 was approximately nine times greater than the capacity in 1977.

The rock wool board system is also popular because the fire safety requirements in some European countries for the construction of schools, hospitals and public buildings are relatively high. This type of insulation can be used to achieve the Class A combustion performance (noncombustible material). For example, although the market share for rock wool in ETICS in Germany is less than $10 \%$, it represents $100 \%$ of the market for buildings taller than $22 \mathrm{~m}$ because the fire codes preclude the use of flammable sheathing products above that height.

\footnotetext{
${ }^{4}$ EIMA web site, August 2012
} 


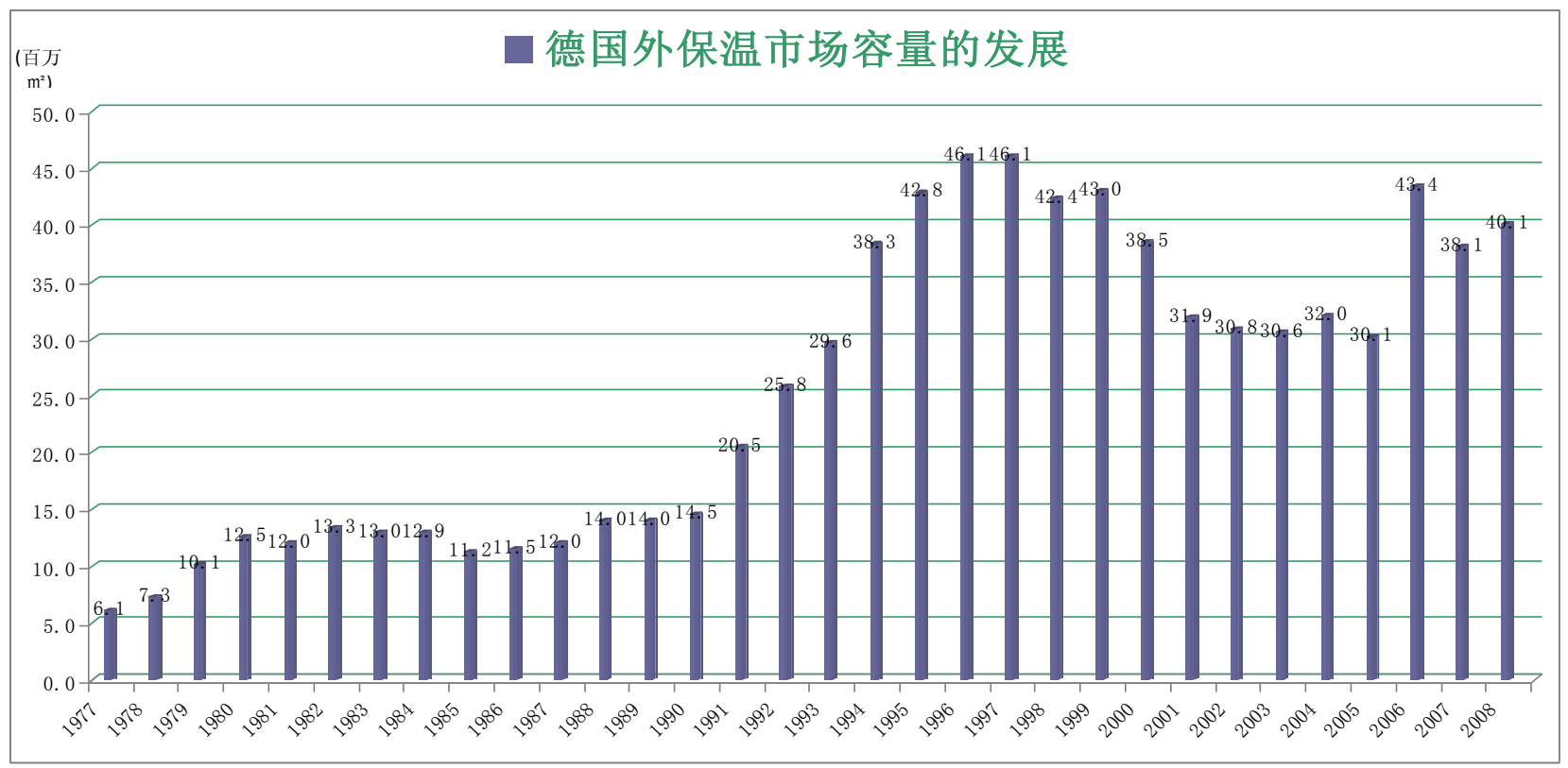

Figure 3 Germany exterior insulation market capacity development (1977-2008)

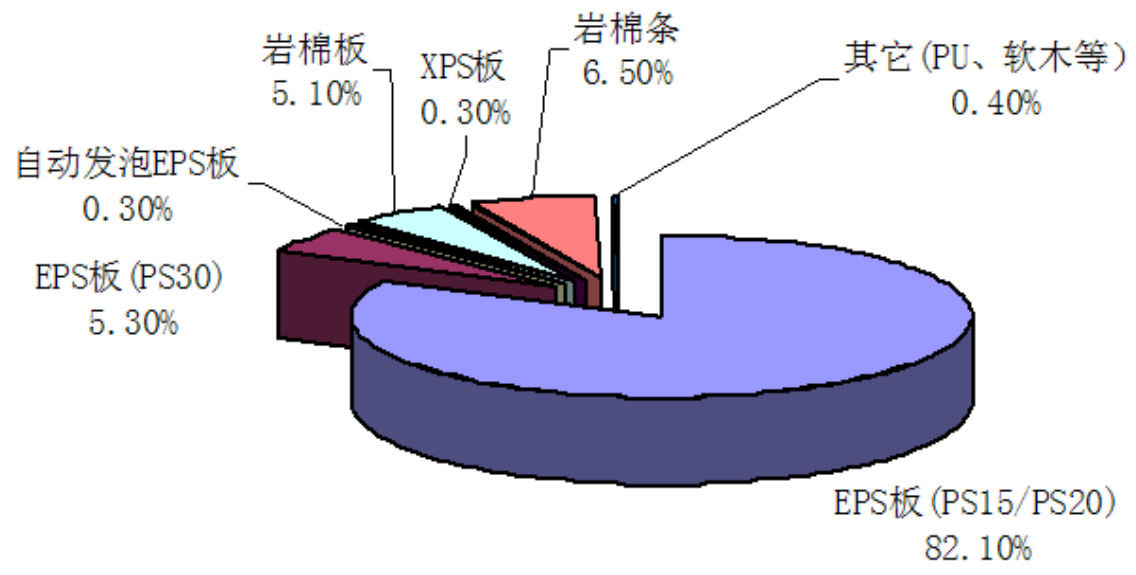

Figure 4 German exterior insulation market shares for various types of insulation materials

The first rock wool board exterior wall insulation system entered the German market in 1976. Initially, a combination of rock wool and EPS boards was used to provide a low thermal conductivity of $0.04 \mathrm{~W} /(\mathrm{m} \cdot \mathrm{K})$, with better sound insulation. But in the early $1990 \mathrm{~s}$, in order to improve the economy of the rock wool exterior insulation and finish systems, the industry developed a system that could be constructed more quickly using rock wool strips instead of the original rock wool board. The new system was based upon a vertical orientation for rock wool products for tall buildings. This arrangement aligned the tensile strength and the protective surface layer bond strength perpendicular to the walls, so that it was no longer necessary to use fixed anchor bolts. The simpler adhesive method greatly shortened the construction time. Also, by improving the compressive strength of the rock wool plate surface, the anchor bolt stress is evenly distributed throughout the rock wool board, so that the system has higher mechanical 
strength. After the mid-1990s, production process improvements also produced a rock wool board thermal conductivity of $0.035 \mathrm{~W} /(\mathrm{m} \cdot \mathrm{K})$.

In Nordic countries, rock wool is the most common insulation product used in ETICS. The dominance of this material is further enhanced by the efforts of a strong business in the locally produced insulation materials.

With the stricter requirements of the EU building energy efficiency standards EnEN 2002, European countries began to focus on materials with better insulating properties, including XPS, polyurethane (PU), phenolic resin and other materials. However, these insulation materials have not been widely used. In 2005, multiple EU countries began collaborative research using vacuum insulation panels (VIP) in exterior wall insulation applications. The thermal insulation capacity of vacuum insulation panels is one of the best, with a nominal thermal conductivity value of 4 to $5 \mathrm{~mW} /(\mathrm{m} \cdot \mathrm{K})$. But, depending on the structure, the actual effective value is 8 to $10 \mathrm{~mW} /(\mathrm{m} \cdot \mathrm{K})$. Also, it is difficult for this system to serve as an element of the mechanical wall structure without the possibility of damage to the vacuum panels. Therefore, as of 2007 , the vacuum panel system had not obtained a permit in Europe, and is only recognized as applicable in special cases. This technology has so far failed to achieve a broad level of acceptance.

\subsubsection{China}

When China began to work on wall insulation in the 1980s, the most common practice was to place the insulation inside the external walls. However, as energy efficiency standards advanced, this method of insulating exterior walls showed of shortcomings, such as: materials, construction, surface cracking, complicated internal building renovation or repurposing. The internal wall insulation method reduced the occupied indoor useable space and introduced thermal bridges from the building interior to other parts of the ring beam, slab, structural column, and so on. In contrast, placing the insulation on the exterior of the wall offers many advantages, including:

- a wide range of applications, including both new and existing buildings, conducive to renovation,

- conserves interior space,

- more complete insulation effect without thermal bridges,

- plasticity, able to provide a climate-protective surface, and

- simple and efficient construction techniques which are easy to grasp.

For these reasons, external wall insulation is now the leading wall insulation technology in China. As the exterior insulation technology matured, more government agencies became involved, such as the Construction Bureau Research Institutes and the Beijing Residential Corporation. These agencies all carried out exterior insulation pilot projects with good results. Since then, with the introduction of the U.S. and European technology, and the continuous improvement of exterior insulation systems, the technology has found a wider range of applications in China.

At that time this system began to spread in China, the technology of ETICS already had more than 30 years of application history in foreign countries, with a set of mature standards to support the technology system. China wanted to develop their own ETICS model, drawing on the proven technology from other nations, but making appropriate changes for China's national conditions. This was known as the Independent Innovation Path. Thus, the national experts, in cooperation with the U.S. Patent Witt, compiled the first library of national standards for exterior insulation and building construction (designated as the Witt exterior insulation and decoration 
system). The library of standards includes the relevant norms and standards, test methods, materials and systems performance requirements, and construction requirements. The library of standards guides architects in the proper role of ETICS in the building structural design. These test methods were developed appropriate for China national circumstances, and are therefore not equivalent to the relevant European, British, and U.S. standards listed in the next section. Many of the standards are included within the China national standards library.

In recent years, China has rapidly developed exterior insulation technology, and the appropriate standards and norms are constantly established and improved. Many of these standards are listed in the next section. New product standards are also in preparation, including:

- extruded polystyrene plastered exterior insulation and finish systems,

- exterior insulation decorative board insulation technology requirements,

- technical requirements for exterior insulation and reinforcements,

- fire test methods for the building's exterior exterior insulation system, and

- technical specification for polyurethane foam insulation and waterproofing project.

At present, the installed costs of exterior insulation systems are slightly higher than interior thermal insulation, but on a cost performance basis, the exterior insulation is better than interior insulation. A large number of engineering practice, design, and construction companies and project developers have gradually formed a consensus favoring the exterior insulation system. In the past two years, exterior insulation has been used on more than $50 \%$ of new residential projects in Beijing, becoming the leading regional wall insulation. With the further development of the Chinese wall insulation system, wall insulation standards will be revised again to make them more complementary and consistent, and will be based on China's national conditions. China's market holds large potential as it continues to move closer to the the advanced international level.

Today, there are three systems of exterior insulation technology in China:

1) Insulation board - fiberglass mesh - polymer mortar system

This system is similar to the system currently used in Europe and the U.S. Insulation in board form is affixed (either mechanically or with adhesive) to a substrate. A protective layer of polymer morter, including a reinforcing mesh, is then applied to provide a durable external surface.

2) Cast-in-place concrete templates with built-in insulation board system

This system is developed for the concrete exterior wall. Insulation in a board form (usually polystyrene) is placed on the inside of the concrete form, with the insulation board in contact with the wall of concrete on the pre-processing side of the recess, in order to better integrate the insulation with the wall. Such a system is characterized by the completed construction and structural placement of the insulation layer, which can reduce the construction period, save binder, and provide a reliable connection with the primary wall. After the mold release, this system has roughly the same protective layer of mortar, fiberglass mesh construction technology and finish as the insulation board system.

3) Pellets of polystyrene thermal insulation mixed with mortar system

This system mixes small pellets of polystyrene thermal insulation with mortar, which is then applied (mechanically sprayed or hand-applied) over a protective layer of fiberglass mesh reinforcement. This system offers less insulation value than the other two systems because the mortar provides an effective thermal short circuit around the insulation pellets. That is why this system is little used today. The benefits of this system are its simplicity and the ability to adapt to complex building wall surfaces. 
The above three technically mature systems account for the majority of engineered Chinese building wall insulation. The overall quality is good, but there are some quality problems. More competition for lower prices can lead to the use of poor materials and shoddy construction, such as polystyrene board of a low density or manufactured without adequate fire-retardant chemicals that is not accordance with the regulations, selection of alkali-resistant fiberglass mesh cloth that does not meet the regulations, polymer mortar performance that does not meet the requirements, and so on.

\subsection{Data Sources for Wall Insulation System Standards}

After years of theoretical research and engineering practice, Europe and the United States have formed a sound system of standards for the exterior insulation and finish systems. Most of these standards are periodically revised to reflect improved practices.

The relevant European standards include:

- EOTA ETAG-004 (2008) Guideline For European Technical Approval Of External Thermal Insulation Composite Systems With Rendering

- PrEN13499 Thermal insulation products for buildings - External thermal insulation composite systems with renders (ETICS) - Specifications

- PrEN13497 - Thermal Insulation Products For Building Applications - Determination Of The Resistance To Impact Of Thermal Insulation Composite Systems (ETICS)

- PrEN13494 - ETICS Determination of the tensile strength of the adhesive and the basecoat to the thermal insulation material

- PrEN 13496 - Thermal insulation products for building applications Determination of the mechanical properties of glass fibre meshes

- And more than 30 others for materials and test methods

The relevant British standards include:

- BS EN 13499:2003 - Thermal insulation products for buildings. Specification for external thermal insulation composite systems (ETICS) based on expanded polystyrene.

- BS EN 13500:2003 - Thermal insulation products for buildings. External thermal insulation composite systems (ETICS) based on mineral wool.

The relevant U.S. standards include:

- ANSI/EIMA - 99A American National Standard for Exterior Insulation and Finish Systems (EIFS)

- ASTM E2568 (replaced ICC ES AC219) - Standard Specification for PB Exterior Insulation and Finish Systems

- ICC ES AC235 - Acceptance Criteria for EIFS with Drainage

- ASTM E2430 - Standard Specification For Expanded Polystyrene ( EPS ) Thermal Insulation Boards For Use In Exterior Insulation and Finish Systems ( EIFS )

- ASTM E2485 (replaced EIMA 101.01) - Standard Test Method for Freeze/Thaw Resistance of Exterior Insulation and Finish Systems (EIFS) and Water Resistive Barrier Coatings

- ASTM E 2486 (replaced EIMA101.86) - Standard Test Method for Impact Resistance of Class PB and PI Exterior Insulation and Finish Systems (EIFS) 
- $\quad$ ASTM E2570 - Standard Test Methods for Evaluating Water-Resistive Barrier (WRB) Coatings Used under Exterior Insulation and Finish Systems (EIFS) or EIFS with Drainage

- Many supporting ASTM standards for EIFS materials and test methods (B117, C67, C287, C1535, D968, D2247, D2794, D3273, E96, E119, E283, E330, E1233, E1825, E2098, E2110, E2134, E2273, G154, G155)

- $\quad$ Fire performance standards (ASTM E119, ASTM E84, NFPA268, NFPA285).

A number of standards have been established in China. Like the western standards, these are also in various stages of revision and improvement.

- JGJ144-2008 - Exterior Insulation and Finish Technical Specification

- JG149-2003 - Expanded Polystyrene Board Thin Plastering Exterior Insulation And Finish Systems

- JC561.2-2006 - Glass fiber reinforcing mesh Part2: Glass fiber reinforcing mesh for class PB EIFS

- JG/T229-2007 - Putty for external thermal insulating wall systems

- GB50411-2007 - Code for Acceptance of Energy Efficient Building Construction

- JG 158-2004 External Thermal Insulating Rendering Systems Made Of Mortar With Mineral Binder And Using Expanded Polystyrene Granule As Aggregate

- Relevant portions of the China Building Construction Library:

- 02J121-1 - Exterior Insulation Construction

- 99J121-2 - Exterior Insulation Of Building Construction

- 06J121-3 - The Wall Energy-Saving Building Construction

- 06J123 - Energy Saving Construction Of The Wall

- 06J908-1 And 06J908-2 - Public Building Energy-Efficient Construction (Cold Regions Of The Cold Areas, Hot Summer And Cold Winter Zone, The Subtropical Region, Cold In Summer And Warm Winter Zone

- 06J908-7 - Existing Building Energy Saving

- 03J122 - Outer-Wall Interior Thermal Insulation Construction

\subsection{Comparison of Wall Insulation System Standards}

Building wall insulation technology standards are organized in three categories: systems, materials, and test methods. The system standards for EIFS/ETICS contain a variety of external wall insulation requirements and technical parameters. In this section the main Chinese and foreign construction wall insulation system standards are compared.

China's domestic building wall insulation standards were developed based on EU standards and other domestic sources. The reference most used was the EU standard EOTA ETAG004-2008. For wall insulation technology using expanded polystyrene board exterior insulation and finish systems, the British standard BS EN 13499-2003 was the primary guideline.

Therefore, the following two sets of standards were compared: the EOTA ETAG0042008 to JGJ144-2008 (draft); and the British Standard BS EN 13499-2003 to JG149-2003.

\subsubsection{Comparing EOTA ETAG-004 (2008) to JGJ144-2008}

The 2008 European standard for ETICS is based on two previously developed standards from 1988 (UEAtc Directives for the Assessment of External Insulation System for Walls 
(Expanded Polystyrene Insulation Faced with a Thin Rendering)) and 1992 (UEAtc Technical Guide for the Assessment of External Wall Insulation Systems Faced with Mineral Render).

The scope of the EOTA ETAG-004 standard is ETICS with rendering intended for use as external thermal insulation for building walls. The walls are made of masonry (bricks, blocks, stones ...) or concrete (cast on site or as prefabricated panels). The insulation product is bonded or mechanically fastened to the wall and then faced with a rendering consisting of one or more site-applied layers. ETICS can be applied to the vertical wall of new and existing buildings, and to an exterior horizontal or inclined surface that is not exposed to rainfall. The ETICS are designed to give the wall to which they are applied a minimum thermal resistance in excess of 1 $\mathrm{m}^{2}-\mathrm{K} / \mathrm{W}$.

The performance requirements and the related test methods are defined for the following seven aspects:

- Mechanical resistance and stability,

- Fire safety (fire classification in accordance with EN13501-1: 2002 Euro classes: A1-F),

- Environmental health, including the indoor environment (moisture - water absorption, water resistance, impact resistance, water vapor permeability, thermal properties), outdoor environment, and the release of harmful substances,

- Safety in use, including self-support of weight, temperature, water absorption, shrinkage, wind load,

- Protection against noise,

- Energy economy and heat rejection, and

- Aspects of durability and serviceability.

Several tests in ETAG-004 are based on carefully defined cyclic environmental conditions. These include hygrothermal tests with heat-rain cycles and heat-cold cycles. Freezethaw tests are required unless the capillarity tests showed minimal water absorption. Some of the physical tests, including bond strength and impact resistance are performed on test specimens that have completed the environmental cycles. During and at the end of the large scale cyclic hygrothermal experiments, the the following phenomena can not occur to either the reinforced base coat or to the ETICS: surface blistering or peeling; cracking or breakage of the joints between the insulation boards or other elements; render coat/ layer separation; and cracking allowing the water to seep into the insulation layer.

The system durability tests in ANSI/EIMA 99A are based on varying time periods. Some tests require 60 cycles of freezing and thawing; others require 14, 28, 83 or 300 days with exposure to varying conditions

The Chinese standard JGJ144-2008 (Draft) has been developed in order to learn from the mature experience of advanced countries to guide the development of China's exterior thermal insulation technology; and to control and ensure the quality of the exterior insulation works to promote the healthy development of the exterior insulation technology. The standard gives the test methods used to check the required performance of external wall insulation systems, as well as the corresponding provisions for the design and construction. This standard was was first published in 2004. A 2008 update has been distributed to the the community for comments, but has not yet been finalized (as of 2012).

The JGJ144-2008 (Draft) standard gives the basic requirements of the external wall insulation system, the overall performance requirements, design and construction of specific 
provisions, the draft specific requirements, and the specific provisions for project acceptance. The standard covers seven kinds of exterior insulation and finish system construction:

- Adhered insulation board,

- Plastic powder EPS granules in an insulation mortar slurry,

- EPS board cast-in-situ concrete,

- EPS steel mesh panels cast-in-situ concrete,

- EPS granules in a glue slurry used to assemble EPS board,

- On-site sprayed polyurethane,

- Pre-fabricated insulated decorative panels.

These standards can be compared on several factors, including tensile bond strength, the system performance requirements, and structural performance requirements. The following tables compare the specific requirements from the above two standards.

Table 3 Exterior Insulation System Tensile Bond Strength Performance Requirements

\begin{tabular}{|c|c|c|c|c|c|}
\hline \multirow[b]{2}{*}{$\begin{array}{l}\text { Test } \\
\text { items }\end{array}$} & \multirow[b]{2}{*}{$\begin{array}{l}\text { EOTA } \\
\text { ETAG004 }\end{array}$} & \multirow[b]{2}{*}{$\begin{array}{l}\text { ANSI/EIMA } \\
99-A-2001\end{array}$} & \multicolumn{3}{|l|}{ JGJ144 } \\
\hline & & & $\begin{array}{l}\text { Adhered insulation } \\
\text { board, Pre- } \\
\text { fabricated insulated } \\
\text { decorative panels, } \\
\text { EPS board cast-in- } \\
\text { situ concrete }\end{array}$ & $\begin{array}{l}\text { Plastic } \\
\text { powder EPS } \\
\text { granules in } \\
\text { an } \\
\text { insulation } \\
\text { mortar } \\
\text { slurry }\end{array}$ & $\begin{array}{l}\text { EPS granules in } \\
\text { a glue slurry } \\
\text { used to } \\
\text { assemble EPS } \\
\text { board, On-site } \\
\text { sprayed } \\
\text { polyurethane }\end{array}$ \\
\hline $\begin{array}{l}\text { Tensile } \\
\text { bond } \\
\text { strength } \\
(\mathrm{MPa})\end{array}$ & $\begin{array}{l}\geq 0.10, \\
\text { failure } \\
\text { shall not } \\
\text { be in the } \\
\text { interface }\end{array}$ & $\begin{array}{l}\text { No interface } \\
\text { failures except: } \\
<0.1-25 \% \\
\text { adhesive failure } \\
\text { permitted } \\
\geq 0.10 \text { - } 100 \% \\
\text { adhesive failure } \\
\text { permitted }\end{array}$ & $\begin{array}{l}\geq 0.10 \text { destruction } \\
\text { occurs in the } \\
\text { insulation panels }\end{array}$ & $\begin{array}{l}\geq 0.1 \\
\text { destruction } \\
\text { occurs in } \\
\text { the } \\
\text { insulation } \\
\text { panels }\end{array}$ & $\begin{array}{l}\geq 0.10 \text { no } \\
\text { damage at the } \\
\text { interface }\end{array}$ \\
\hline $\begin{array}{l}\text { Pull-out } \\
\text { force for } \\
\text { profiles } \\
\text { and their } \\
\text { fixings }\end{array}$ & $\begin{array}{l}\geq 500 \mathrm{~N} \\
(6.4 .4 .1)\end{array}$ & $\begin{array}{l}\text { Must meet wind } \\
\text { loads in local } \\
\text { building codes }\end{array}$ & & & \\
\hline
\end{tabular}


Table 4 Exterior Insulation System Performance Requirements

\begin{tabular}{|c|c|c|c|}
\hline Characteristic & EOTA ETAG004 & ANSI/EIMA 99-A-2001 & JGJ144 \\
\hline Impact resistance & $\begin{array}{l}\text { Categories of qulitative toughness:Class I- parts of the } \\
\text { building vulnerable to collision such as the ground floor; } \\
\text { Class II - areas easily damaged by thrown items, but the } \\
\text { ETICS can reduce the extent of the damage; Class III - } \\
\text { areas difficult to damage with thrown items }(6.1 .3 .3)\end{array}$ & $\begin{array}{l}\text { Standard Impact } \\
\text { Resistance }-2.8 \mathrm{~J} \\
\text { Medium Impact } \\
\text { Resistance }-5.7 \mathrm{~J} \\
\text { High Impact Resistance } \\
-10.2 \mathrm{~J} \\
\text { Ultra High Impact } \\
\text { Resistance }-17 \mathrm{~J} \\
\end{array}$ & $\begin{array}{l}\text { 10J - Parts of the ground floor } \\
\text { walls vulnerable to collision } \\
\text { with doors or windows; } \\
\text { 3J - Parts of the building above } \\
\text { the second floor where the walls } \\
\text { are less vulnerable to collision }\end{array}$ \\
\hline Water absorption & $\begin{array}{l}\text { If the water absorption of the concrete base wall } \geq 1 \mathrm{~kg} / \\
\mathrm{m} \text { after } 1 \text { hour, ETICS water absorption after } 1 \text { hour } \\
<1 \mathrm{~kg} / \mathrm{m}^{2}(6.1 .3 .1)\end{array}$ & 14 day exposure & $\begin{array}{l}\text { The system is immersed in water } \\
\text { for } 1 \mathrm{~h} \text {; the amount of water } \\
\text { absorbed shall not be greater } \\
\text { than or equal } 1.0 \mathrm{~kg} / \mathrm{m}^{2}\end{array}$ \\
\hline $\begin{array}{l}\text { Resistance to } \\
\text { freeze-thaw } \\
\text { performance }\end{array}$ & $\begin{array}{l}24 \text { hours after the experiment (5.1.4.1.1), the water } \\
\text { absorption of the primary wall and the insulation and } \\
\text { finish systems is }<0.5 \mathrm{~kg} / \mathrm{m}^{2} \\
\text { OR } \\
\text { Meet requirments for satisfactory appearance and joint } \\
\text { stability }(6.1 .3 .2 .1) \text { and bond strength }(6.1 .4 .1 .1 \text { and } \\
6.1 .7 .1) \text { of } 0.08 \mathrm{~N} / \mathrm{mm}^{2} \text { unless rupture occurs in the } \\
\text { insulation product }\end{array}$ & $\begin{array}{l}\text { No cracking, checking, } \\
\text { crazing, erosion, rusting, } \\
\text { blistering, peeling or } \\
\text { delamination after } 60 \\
\text { cycles }\end{array}$ & $\begin{array}{l}\text { No voids, no water seepage } \\
\text { cracks; tensile bond strength to } \\
\text { comply with specified } \\
\text { provisions after } 30 \text { cycles }\end{array}$ \\
\hline $\begin{array}{l}\text { Thermal } \\
\text { resistance }\end{array}$ & $\begin{array}{l}\text { Minimum thermal resistance required }>1 \mathrm{~m}^{2} \mathrm{~K} / \mathrm{W} \text {. } \\
\text { Maximum thermal conductance shall be } 0.065 \mathrm{~W} / \mathrm{m}-\mathrm{K} \\
\text { based upon the total thickness of the composite. }\end{array}$ & $\begin{array}{l}\text { Minimum } 19 \mathrm{~mm} \text { of EPS } \\
\text { or XPS OR minimum of } \\
16 \mathrm{~mm} \text { of PIR }\end{array}$ & Meet the design requirements \\
\hline $\begin{array}{l}\text { Surface layer } \\
\text { impermeability }\end{array}$ & $\begin{array}{l}\text { Water vapor permeability can not exceed: } 2 \mathrm{~m} \text { if } \\
\text { combination involves a cellular plastic insulation } \\
\text { material; } 1 \mathrm{~m} \text { if the comination involves a mineral wool } \\
\text { insulation material. }(6.1 .3 .4)\end{array}$ & $\begin{array}{l}\text { Limits for abrasion, } \\
\text { accelerated weathering, } \\
\text { mildew resistance, salt } \\
\text { spray resistance, water } \\
\text { penetration }(15 \text { minutes } \\
\text { at } 300 \mathrm{~Pa})\end{array}$ & $\begin{array}{l}2 \mathrm{~h} \text { impervious and water vapor } \\
\text { permeability according to design } \\
\text { requirements }\end{array}$ \\
\hline
\end{tabular}


Table 5 Adhesive tensile bond strength performance requirements

\begin{tabular}{|c|c|c|c|c|c|}
\hline \multirow{2}{*}{ 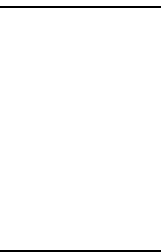 } & \multirow{2}{*}{ Test items } & \multicolumn{2}{|c|}{ EOTA ETAG004 (6.1.4.1) } & \multicolumn{2}{|r|}{ JGJ144 } \\
\hline & & $\begin{array}{l}\text { Between the } \\
\text { adhesive and } \\
\text { the primary } \\
\text { wall }\end{array}$ & $\begin{array}{l}\text { Between adhesive } \\
\text { and insulation } \\
\text { materials } \mathrm{A}\end{array}$ & $\begin{array}{l}\text { With } \\
\text { cement } \\
\text { mortar }\end{array}$ & $\begin{array}{l}\text { Pre-fabricated } \\
\text { insulated } \\
\text { decorative } \\
\text { panels }\end{array}$ \\
\hline \multirow{3}{*}{$\begin{array}{l}\text { Tensile } \\
\text { bond } \\
\text { strength } \\
(\mathrm{MPa})\end{array}$} & $\begin{array}{l}\text { Standard } \\
\text { state }\end{array}$ & $\geq 0.25 \mathrm{~N} / \mathrm{mm}^{2}$ & $\begin{array}{l}\geq 0.08 \mathrm{~N} / \mathrm{mm}^{2} \\
\text { unless rupture } \\
\text { occurs in the } \\
\text { insulation product }\end{array}$ & $\geq 0.60$ & $\begin{array}{l}\geq 0.10 \text { And } \\
\text { destruction of } \\
\text { insulation } \\
\text { panels }\end{array}$ \\
\hline & $\begin{array}{l}\text { After } \\
\text { immersion in } \\
\text { water } 2 \mathrm{~h}\end{array}$ & $\geq 0.08 \mathrm{~N} / \mathrm{mm}^{2}$ & $\geq 0.03 \mathrm{~N} / \mathrm{mm}^{2}$ & \multirow[b]{2}{*}{$\geq 0.40$} & $\begin{array}{l}\geq 0.10 \text { or } \\
\text { insulating } \\
\text { panels damage }\end{array}$ \\
\hline & $\begin{array}{l}7 \text { days after } \\
\text { immersion }\end{array}$ & $\geq 0.25 \mathrm{~N} / \mathrm{mm}^{2}$ & $\begin{array}{l}\geq 0.08 \mathrm{~N} / \mathrm{mm}^{2} \\
\text { unless rupture } \\
\text { occurs in the } \\
\text { insulation product }\end{array}$ & & $\begin{array}{l}\geq 0.10 \text { and } \\
\text { insulation board } \\
\text { damage }\end{array}$ \\
\hline
\end{tabular}

Table 6 Reinforcing Mesh Performance Requirements

\begin{tabular}{|l|l|l|l|}
\hline \multicolumn{1}{|c|}{ Test items } & EOTA ETAG004 & $\begin{array}{l}\text { ANSI/EIMA 99- } \\
\text { A-2001 }\end{array}$ & $\begin{array}{l}\text { JGJ144 (Warp } \\
\text { and Weft) }\end{array}$ \\
\hline $\begin{array}{l}\text { Alkali - resistance } \\
\text { retained tensile } \\
\text { breaking strength }\end{array}$ & \multicolumn{1}{|c|}{10} & $\begin{array}{l}\geq 750 \mathrm{~N} / 50 \mathrm{~mm}(\geq \\
50 \%)\end{array}$ \\
\hline Fiberglass mesh & $\begin{array}{l}\text { The minimum thickness of the } \\
\text { galvanized steel zinc coating is } \\
\text { Metam }\left(\geq 275 \mathrm{~g} / \mathrm{m}^{2}\right) \text {, galvanizing } \\
\text { must be done after the required } \\
\text { welding (grid spacing of 9- } \\
13 \mathrm{~mm})\end{array}$ & & \\
\hline
\end{tabular}


Table 7 Insulation board performance requirements

\begin{tabular}{|c|c|c|c|c|c|c|}
\hline \multirow{2}{*}{ Test items } & \multirow[t]{2}{*}{ ETAG-004 } & \multicolumn{2}{|c|}{ ANSI/EIMA 99-A-2001 } & \multicolumn{3}{|c|}{ JGJ144 } \\
\hline & & EPS and XPS & PIR & EPS & XPS & $\mathrm{PU}$ \\
\hline Density $\left(\mathrm{kg} / \mathrm{m}^{3}\right)$ & & 15 & & $8-22$ & $25-35$ & $\geq 40$ \\
\hline $\begin{array}{l}\text { Compressive } \\
\text { resistance } \\
(\mathrm{kPa})\end{array}$ & & $\geq 69$ & $\geq 110$ & & & \\
\hline $\begin{array}{l}\text { Thermal } \\
\text { conductivity } \\
{[\mathrm{W} /(\mathrm{m} \cdot \mathrm{K})]}\end{array}$ & & $\leq 0.040$ & $\leq 0.026$ & $\leq 0.039$ & $\leq 0.030$ & $\leq 0.024$ \\
\hline $\begin{array}{l}\text { Tensile } \\
\text { strength(MPa) }\end{array}$ & $\begin{array}{l}\text { The tensile } \\
\text { strength of the } \\
\text { vertical surface } \\
\text { in wet } \\
\text { conditions } \geq \\
50 \% \text { of the } \\
\text { tensile strength } \\
\text { under dry } \\
\text { conditions } \\
\text { (6.2.4.1) } \\
\end{array}$ & & $\geq 0.024$ & $\geq 0.10$ & $\geq 0.10$ & $\geq 0.10$ \\
\hline $\begin{array}{l}\text { Size stability } \\
(\%)\end{array}$ & & $\leq 2.0$ & $\leq 2.0$ & $\leq 0.5$ & $\leq 1.0$ & $\leq 1.0$ \\
\hline $\begin{array}{l}\text { Shear } \\
\text { properties }\end{array}$ & $\begin{array}{l}\text { Characteristic } \\
\text { shear strength } \\
\geq 0.02 \mathrm{~N} / \mathrm{mm}^{2} \\
(\mathrm{MPa}) \text { and the } \\
\text { mean shear } \\
\text { modulus } \geq 1 \text {. } \\
\mathrm{N} / \mathrm{mm}^{2}(6.2 .4 .2)\end{array}$ & $\begin{array}{l}\text { Flexural } \\
\text { strength } \geq \\
0.17 \mathrm{MPa}\end{array}$ & $\begin{array}{l}\text { Flexural } \\
\text { strength } \\
\geq 0.28 \mathrm{MPa}, \\
\text { break load } \\
\geq 75 \mathrm{~N}\end{array}$ & & & \\
\hline $\begin{array}{l}\text { Combustion } \\
\text { properties }\end{array}$ & & $\begin{array}{l}\text { Flame spread } \\
\text { smoke devel } \\
\text { ASTM E84 }\end{array}$ & $\begin{array}{l}\leq 25 \text { and } \\
\text { ped } \leq 450 \text { per }\end{array}$ & Not less & an class 1 & \\
\hline $\begin{array}{l}\text { Water } \\
\text { absorption }\end{array}$ & $\begin{array}{l}\leq 1 \mathrm{~kg} / \mathrm{m} 2 \text { after } \\
24 \text { hours partial } \\
\text { immersion }\end{array}$ & $\begin{array}{l}\leq 4 \text { volume } \\
\% \text { after } 24 \mathrm{~h} \\
\text { full } \\
\text { submersion }\end{array}$ & $\begin{array}{c}\leq 2 \text { volume } \\
\% \text { after } 2 \mathrm{~h} \\
\text { full } \\
\text { submersion }\end{array}$ & & & \\
\hline $\begin{array}{l}\text { Water vapor } \\
\text { permeance }\end{array}$ & & $\begin{array}{c}\leq 287 \mathrm{ng} / \mathrm{Pa}- \\
\mathrm{s}-\mathrm{m}^{2} \text { for } \\
25.4 \mathrm{~mm} \\
\text { thickness }\end{array}$ & $\begin{array}{c}\leq 86 \mathrm{ng} / \mathrm{Pa}- \\
\mathrm{s}-\mathrm{m}^{2} \text { for } \\
25.4 \mathrm{~mm} \\
\text { thickness }\end{array}$ & & & \\
\hline
\end{tabular}

\subsubsection{Comparing BS EN 13499-2003 with JG149-2003}

The 2003 standard, BS EN 13499-2003 Thermal Insulation Products for Buildings External Thermal Insulation Composite Systems (ETICS) Based On Expanded Polystyrene, was developed by CEN/TC88 (European Committee for Standardization - Technical Committee) 
under the guidance of the Insulation Materials and products Technical Committee secretariat managed by DIN (German Standards Committee). According to the rules of the CEN/CENELEC (the common European Organization for Standardization), the national standards bodies of the following countries contributed to this standard: Austria, Belgium, Czech Republic, Denmark, Finland, France, Germany, Greece, Hungary, Iceland, Ireland, Italy, Luxembourg, Malta, Netherlands, Norway, Portugal, Slovakia, Spain, Sweden, Switzerland and the United Kingdom.

The scope of BS EN 13499-2003 includes: (1) Specifies the requirements for factory made products for external thermal insulation composite systems (ETICS) based on expanded polystyrene, delivered as a kit, and used as thermal insulation for buildings; (2) Describes product characteristics, including test procedures, marking, and labeling; (3) ETICS are applied to external wall surfaces for new or existing buildings to improve thermal performance, and may include special fittings in order to connect with the adjacent building structures, ETICS helps to resist wind erosion and improve the appearance of the buildings aesthetics, and but does not contribute to wall or soffit stability; (4) The standard includes systems where the thermal insulation material is required for the load transfer to the substrate; (5)The system must have a nominal thermal resistance equal to or greater than $1 \mathrm{~m}^{2} \cdot \mathrm{K} / \mathrm{W}$; and (6) The standard does not cover the strength between the ETICS and the building surface, or substrate. The standard references 24 other EN standards or draft standards for test procedures and material standards.

Several standards were evaluated during the development of the China standard JG1492003, Expanded Polystyrene Board Exterior Wall External Thermal Insulation System, but the technical performance indicators were adjusted to meet the needs of China's national conditions. The standards reviewed included:

- EOTA ETAG004 - Guideline For European Technical Approval Of External Thermal Insulation Composite Systems With Rendering,

- Austrian standard ÖNORM B 6110 - External Thermal Insulating Composite Systems (ETICS) With Rendering On Expanded Polystyrene Foam Based EPS-F - Marking Of Conformity (issued in 1998 and withdrawn in 2007),

- CEN/TC88/WG 18, N166 - Expanded Polystyrene Vinyl Exterior Thermal Insulation Composite System Specification, and

- ICBO ES AC24 - Interim Criteria For Exterior Insulation And Finish Systems (This document was later replaced by AC 219 Acceptance Criteria for Exterior Insulation and Finish Systems, AC 235 Acceptance Criteria for EIFS Clad Drainage Wall Assemblies, and AC 212 Acceptance Criteria for Water-Resistive Coatings Used as Water-Resistive Barriers over Exterior Sheathing. AC219 was later released as ASTM E2568 amd AC 212 was later released as ASTM E2570.)

The scope of standard JG149-2003 specifies the definition, classification and marking of expanded polystyrene board exterior wall insulation system products, requirements, test methods, inspection rules, product certification and manual, as well as product packaging, transportation and storage. The insulation systems are for industrial and civil buildings. The previously discussed standard, JGJ144-2008, includes references to both JG149 and ETAG004. Therefore, JG149 and JGJ144 are consistent indicators of the same project requirements and are not in conflict. Specific sections of JG149 and BS EN 13499 are compared in the following tables. 
Table 8 Facing material requirements

\begin{tabular}{|c|c|c|c|c|}
\hline Test & \multicolumn{2}{|c|}{ BS EN 13499} & \multicolumn{2}{|l|}{ JG149 } \\
\hline $\begin{array}{l}\text { Water absorption }(\mathrm{g} / \\
\left.\mathrm{m}^{2}\right), \text { immersed } 24 \mathrm{~h}\end{array}$ & \multicolumn{2}{|c|}{$\leq 1000$} & \multicolumn{2}{|l|}{$\leq 500$} \\
\hline \multirow{2}{*}{ Impact resistance $(\mathrm{J})$} & $\mathrm{I} 2$ & $\geq 2.0$ & Common $(\mathrm{P})$ & $\geq 3.0$ \\
\hline & $\mathrm{I} 10$ & $\geq 10.0$ & Enhanced (Q) & $\geq 10.0$ \\
\hline \multirow{2}{*}{$\begin{array}{l}\text { Penetration } \\
\text { resistance }(\mathrm{N})\end{array}$} & $\mathrm{I} 2$ & $>200$ & \multirow{3}{*}{\multicolumn{2}{|c|}{$\begin{array}{l}\text { Wind load of not less than the } \\
\text { project design value }^{\mathrm{A}}\end{array}$}} \\
\hline & $\mathrm{I} 10$ & $>500$ & & \\
\hline $\begin{array}{l}\text { Wind load } \\
\text { resistance value } \\
(\mathrm{KPa})\end{array}$ & \multicolumn{2}{|c|}{$\begin{array}{l}\text { Wind load of not less than the project } \\
\text { design value }\end{array}$} & & \\
\hline $\begin{array}{l}\text { Resistance to } \\
\text { freezing and } \\
\text { thawing }\end{array}$ & & & \multicolumn{2}{|c|}{$\begin{array}{l}\text { Surface free of cracks, } \\
\text { hollowing, bubbles, peeling }\end{array}$} \\
\hline $\begin{array}{l}\text { Water vapor } \\
\text { permeability }\end{array}$ & \multicolumn{2}{|c|}{$\geq 20 \mathrm{~g} /\left(\mathrm{m}^{2} \cdot \mathrm{d}\right)$} & \multicolumn{2}{|c|}{$\geq 0.85 \mathrm{~g} /\left(\mathrm{m}^{2} \cdot \mathrm{h}\right)\left(\geq 20 \mathrm{~g} /\left(\mathrm{m}^{2} \cdot \mathrm{d}\right)\right)$} \\
\hline $\begin{array}{l}\text { Liquid water } \\
\text { Permeability }\end{array}$ & \multicolumn{2}{|c|}{$\begin{array}{l}<0.5 \mathrm{~kg} /\left(\mathrm{m}^{2} \cdot \mathrm{h}^{0.5}\right) \text {. If the base coat } \\
\text { satisfies requirements, no need to test } \\
\text { facing materials }\end{array}$} & \multicolumn{2}{|c|}{$\begin{array}{l}\text { No water penetration of the } \\
\text { inside of a sample protective } \\
\text { layer }\end{array}$} \\
\hline Weather resistance & \multicolumn{2}{|c|}{ - } & \multicolumn{2}{|c|}{$\begin{array}{l}\text { Surface free of cracks, chalking, } \\
\text { spalling phenomenon }\end{array}$} \\
\hline
\end{tabular}

Table 9 Adhesive performance requirements for exterior insulation system

\begin{tabular}{|c|c|c|c|}
\hline \multirow{3}{*}{$\begin{array}{l}\text { Tensile bond strength } \\
\text { Between base coat and } \\
\text { EPS board (MPa) }\end{array}$} & \multicolumn{2}{|l|}{ JG149 } & \multirow{2}{*}{$\begin{array}{r}\text { BS EN } 13499 \\
\geqq 0.08\end{array}$} \\
\hline & Original & $\geqq 0.6$ & \\
\hline & $\begin{array}{l}\text { After exposure to } \\
\text { water }\end{array}$ & $\geqq 0.4$ & $\cong 0.08$ \\
\hline \multirow{2}{*}{$\begin{array}{l}\text { Tensile bond strength of } \\
\text { adhesive between } \\
\text { substrate and EPS board } \\
(\mathrm{MPa})\end{array}$} & Original & $\geqq 0.1$ & \multirow[t]{2}{*}{$\geqq 0.08^{\mathrm{A}}$} \\
\hline & $\begin{array}{l}\text { After exposure to } \\
\text { water }\end{array}$ & $\geqq 0.1$ & \\
\hline $\begin{array}{l}\text { Durability and adhesion } \\
\text { of finishing material on } \\
\text { base coat }\end{array}$ & & & $\begin{array}{l}\text { No blistering, quantity and quality } \\
\text { of cracks and flakes limited }\end{array}$ \\
\hline Operating time (h) & $1.5-4.0$ & & - \\
\hline
\end{tabular}


Table 10 Product requirements for expanded polystyrene board used in ETICS

\begin{tabular}{|c|c|c|c|c|}
\hline Project & \multicolumn{2}{|c|}{ JG149 } & \multicolumn{2}{|l|}{ BS EN 13499} \\
\hline Thermal insulation properties & \multicolumn{2}{|c|}{$\begin{array}{l}\text { Thermal } \\
\text { conductivity } \\
\leqq 0.041 \mathrm{~W} /(\mathrm{m} \cdot \mathrm{K})\end{array}$} & \multicolumn{2}{|c|}{$\begin{array}{l}\text { Nominal thermal resistance } R_{D} \geqq \\
1.00 \mathrm{~m}^{2} \cdot \mathrm{K} / \mathrm{W}\end{array}$} \\
\hline \multirow{3}{*}{$\begin{array}{l}\text { Vertical surface tensile strength } \\
\text { (MPa) }\end{array}$} & \multirow{3}{*}{\multicolumn{2}{|c|}{$\geqq 0.1$}} & Adhesive fixed EPS & $\geqq 0.1$ \\
\hline & & & Anchors fixed EPS & $\geqq 0.1$ \\
\hline & & & Profiles fixed EPS & $\geqq 0.15$ \\
\hline Dimensional stability & \multicolumn{2}{|c|}{$\leqq 0.3 \%$} & \multicolumn{2}{|l|}{ $\pm 0.2 \%$} \\
\hline Squareness tolerances & \multicolumn{2}{|c|}{ - } & \multirow{2}{*}{\multicolumn{2}{|c|}{ $\pm 2 \mathrm{~mm} / \mathrm{m}$}} \\
\hline Flatness/smoothness tolerance & \multicolumn{2}{|c|}{ $\pm 1.0 \mathrm{~mm}$} & \multirow{2}{*}{\multicolumn{2}{|c|}{$\frac{ \pm 5 \mathrm{~mm}}{ \pm 2 \mathrm{~mm}}$}} \\
\hline Length tolerance & \multirow{2}{*}{\multicolumn{2}{|c|}{$\begin{array}{l} \pm 2.0 \mathrm{~mm} \\
\pm 1.0 \mathrm{~mm}\end{array}$}} & & \\
\hline Width tolerance & & & \multicolumn{2}{|l|}{ $\pm 2 \mathrm{~mm}$} \\
\hline \multirow{2}{*}{ Thickness tolerance } & $\leqq 50 \mathrm{~mm}$ & $\pm 1.5 \mathrm{~mm}$ & \multirow{2}{*}{\multicolumn{2}{|c|}{ $\pm 1 \mathrm{~mm}$}} \\
\hline & $>50 \mathrm{~mm}$ & $\pm 2.0 \mathrm{~mm}$ & & \\
\hline Diagonal difference & \multicolumn{2}{|c|}{ $\pm 3.0 \mathrm{~mm}$} & \multicolumn{2}{|l|}{ - } \\
\hline Panel edge straightness & \multicolumn{2}{|c|}{ $\pm 2.0 \mathrm{~mm}$} & \multicolumn{2}{|l|}{ - } \\
\hline $\begin{array}{l}\text { Long-term water absorption of } \\
\text { partially submerged }\end{array}$ & \multicolumn{2}{|c|}{-} & \multicolumn{2}{|l|}{$\leqq 0.5 \mathrm{~kg} / \mathrm{m}^{2}$} \\
\hline \multicolumn{5}{|c|}{$\begin{array}{l}\text { Note 1: in the table JG149 } 1200 \mathrm{~mm} \text { long x } 600 \mathrm{~mm} \text { wide expansion of allowable deviation value } \\
\text { polystyrene board shall prevail. } \\
\text { Note 2: Table of BS EN } 13499 \text { anchors or profile fixed with adhesive EPS board shall be treated } \\
\text { in accordance with the adhesive system. }\end{array}$} \\
\hline
\end{tabular}

Table 11 Product requirements for base coat used in ETICS

\begin{tabular}{|c|c|c|c|}
\hline \multirow{4}{*}{\begin{tabular}{|l|}
\multicolumn{1}{|c}{ Project } \\
Tensile bond \\
strength with \\
expanded \\
polystyrene \\
board (MPa)
\end{tabular}} & \multicolumn{2}{|c|}{ JG149 } & BS EN 13499 \\
\hline & Original intensity & $\geqq 0.1$ & \multirow{3}{*}{$\geqq 0.08$} \\
\hline & After exposure to water & $\geqq 0.1$ & \\
\hline & $\begin{array}{l}\text { Resistance to freezing and } \\
\text { thawing }\end{array}$ & $\geqq 0.1$ & \\
\hline \multirow{2}{*}{ Flexibility } & $\begin{array}{l}\text { Compressive } \\
\text { strength/flexural strength }\end{array}$ & $\leqq 3.0$ & - \\
\hline & $\begin{array}{l}\text { Cracking strain (non- } \\
\text { cement-based) (\%) }\end{array}$ & $\geqq 1.5$ & - \\
\hline $\begin{array}{l}\text { Operational time } \\
\text { (h) }\end{array}$ & \multicolumn{2}{|l|}{$1.5-4.0$} & - \\
\hline
\end{tabular}


Table 12 Product requirements for reinforcing mesh used in ETICS

\begin{tabular}{|l|c|c|}
\hline \multicolumn{1}{|c|}{ Project } & $\begin{array}{l}\text { JG149 (Alkali } \\
\text { resistant mesh) }\end{array}$ & $\begin{array}{l}\text { BS EN 13499 } \\
\text { (Reinforced } \\
\text { materials) }\end{array}$ \\
\hline Mass per unit area $\left(\mathrm{g} / \mathrm{m}^{2}\right)$ & $\geqq 130$ & - \\
\hline Alkali crack strength (warp and weft) & $\geqq 750 \mathrm{~N} / 50 \mathrm{~mm}$ & $\begin{array}{c}\geqq 40 \mathrm{~N} / \mathrm{mm}, \\
\text { Each } \\
\text { value not less } \\
\text { than } 36 \mathrm{~N} / \mathrm{mm}\end{array}$ \\
\hline $\begin{array}{l}\text { Alkali crack strength retention (warp and weft) }(\% \text { of } \\
\text { initial tensile strength) }\end{array}$ & $\geqq 50$ & $\vdots 50$ \\
\hline Fracture strain $(\%)$ & $\leqq 5.0$ & - \\
\hline Tensile strength to Elongation at failure, $\mathrm{kN} / \mathrm{mm}$ & & $\vdots 1$ \\
\hline $\begin{array}{l}\text { Minimum thickness zinc coat for galvanized lath or } \\
\text { mesh (galvanizing to take place after welding mesh) }\end{array}$ & & $\begin{array}{l}20 \mu \mathrm{m}(\geqq 257 \\
\mathrm{g} / \mathrm{m} 2)\end{array}$ \\
\hline Spacing between filament for metal lath or mesh & & 9 to $19 \mathrm{~mm}$ \\
\hline
\end{tabular}

Table 13 Product requirements for anchors used in ETICS

\begin{tabular}{|l|l|l|}
\hline Project & JG149 & \multicolumn{1}{|c|}{ BS EN 13499 } \\
\hline $\begin{array}{l}\text { Single anchor bolt tension } \\
\text { strength standard value }(\mathrm{kN})\end{array}$ & $\geqq 0.30$ & $\begin{array}{l}\text { The ETICS design anti-pull force the shall be } \\
\text { greater than the wind load design negative pressure, } \\
\text { with a partial safety factor } \leqq 1.5\end{array}$ \\
\hline $\begin{array}{l}\text { Additional heat transfer per } \\
\text { single anchor bolt on the } \\
\text { system }\left(\mathrm{W} /\left(\mathrm{m}^{2} \cdot \mathrm{K}\right)\right)\end{array}$ & $\begin{array}{l}\leqq \\
0.004\end{array}$ & - \\
\hline
\end{tabular}

\section{BUILDING STOCK}

\subsection{Data Sources for U.S. Buildings}

The U.S. Energy Information Administration (EIA) $(1,2)$ provides detailed information about the current U.S. building stock. The information can broadly be classified into:

- Residential Energy Consumption Survey (RECS)

- Commercial Buildings Energy Consumption Survey (CBECS)

The EIA website provides information about the residential housing sector in terms of housing characteristics and energy consumption. Based on the 2009 RECS, there were 113.6 million houses in the U.S. These include single-family units, apartment buildings and mobile homes. The total housing units have been further subdivided into classes based on characteristics like space heating, air conditioning, structural and geographic characteristics, etc. The most recent commercial survey was conducted in 2003, according to which there were $4,859,000$ commercial buildings in the U.S. with a total floorspace of $6.7 \mathrm{E} 9 \mathrm{~m}^{2}$ (72E9 square feet). 
EIA also provides information regarding the energy consumption of the building sector. According to the Annual Energy Outlook 2011 (3), the 2011 energy consumption by the residential and commercial sectors is estimated to be 2.2E9 and 2.0E9 GJ (21 and 18 quadrillion BTUs), respectively; the delivered energy consumption is 1.2E9 and 9.1E8 GJ (11 and 8.7 quadrillion BTUs), respectively.

\subsection{Data Sources for China Buildings}

Pacific Northwest National Laboratory published a series of reports based on the building stock and codes in the Asia-Pacific region (4-6). According to one of the reports focused on China (6), existing buildings in China covered about 38 billion $\mathrm{m}^{2}$ (409 billion square feet) at the end of 2003. The report further stated that about 2 billion $\mathrm{m}^{2}$ (20 billion square feet) are being added annually to the Chinese building stock in recent years (6), making it the world's largest construction market. In 2011 alone, more than 5 billion $\mathrm{m}^{2}$ (55 billion square feet) of floor space was under construction (36). Approximately $45 \%$ of the population lives in high density urban areas, and that proportion is expected to increase (34). The total number of households is estimated at 373 million in 2007 (34) and the urban density was about 750 persons/sq. km (35).

\subsection{Weatherization and Retrofit Activities in the U.S.}

Although the focus on buildings in China is often placed on new construction in urban areas, a large portion of the population still lives in existing smaller buildings in the agricultural regions. In order to explore potential energy-saving strategies for these buildings, retrofit activities in the U.S. were reviewed. Particular attention was placed on programs for lowincome homes.

The U.S. Department of Energy (DOE) Weatherization and Intergovernmental Program provides grants, technical assistance, and information tools to states, local governments, community action agencies, utilities, Indian tribes, and overseas U.S. territories for their energy programs (16). The Weatherization Assistance Program is one part of that larger program, and is designed for making low-income single-family homes more energy efficient. The program's website (http://waptac.org/) provides information on the low-income weatherization program, including rules and guidance, technical tools, best practices, training resources, etc.

Table 14 provides a list of weatherization measures from a weatherization field standards document effective March 2009 from a U.S. state spanning climate zones 4 and 5. The measures are listed in the order of priority. The field standards document also describes in detail the procedures for pre- and post-weatherization inspections, energy audits, field monitoring and diagnostic testing. Weatherization standards for several other U.S. states in different climate zones may be found at the website.

A metaevaluation of the WAP was performed by Oak Ridge National Laboratory (ORNL), using data from studies of weatherization efforts in 19 different states that were completed between 1993 and 2005 (17). Previously, three such metaevaluations were performed between 1996 and 2002. These metaevaluations focused primarily on energy savings in natural gas heated homes since the majority of state-level studies addressed that fuel. Insufficient data were available to make reliable savings estimates in electrically heated homes and in homes using electricity for non-heating purposes. The 2005 metaevaluation found average annual site energy savings of 32 GJ (31 million BTUs) per gas-heated household. The per-household energy savings estimated were $23 \%$ of pre-weatherization consumption of natural gas for all end uses. 
More information regarding past and current evaluation studies can be found at http://weatherization.ornl.gov/evaluation past.shtml.

Table 14 Priority list of weatherization measures for site-built homes.

\begin{tabular}{|c|c|}
\hline $\begin{array}{l}\text { 1. Heating System: } \\
\text { Clean and Tune }\end{array}$ & Mandatory Measure. \\
\hline 2. Air Sealing & $\begin{array}{l}\text { Mandatory measures: Use blower door to guide air sealing. } \\
\text { Ducts must be sealed as per blower door guided and duct } \\
\text { diagnostic standards. Seal ducts only if they are outside thermal envelope. } \\
\text { Home must be sealed at least to upper limit of the target range } \\
\text { and any other significant or obvious air leaks. Seal all major bypasses } \\
\text { and key junctures. Attics/ceilings must be sealed prior to installation of } \\
\text { attic insulation. }\end{array}$ \\
\hline 3. Duct Insulation & $\begin{array}{l}\text { Mandatory measure: After sealing ducts outside the thermal } \\
\text { envelope, insulate the same ducts. }\end{array}$ \\
\hline 4. Attic Insulation & $\begin{array}{l}\text { Mandatory measure: Insulate attics to R-38 if existing } \\
\text { insulation is less than R-11. If there is even and consistent existing R- } \\
11 \text { to } \mathrm{R}-19 \text {, attic insulation, go to priority \#6, and priorities \#5 and \#6 move } \\
\text { up to \#4 and \#5. If existing is consistent R-11, attic insulation to R-38 is a } \\
\text { recommended measure. If existing is consistent R-19, attic insulation to } \\
\mathrm{R}-38 \text { is allowable. Mandatory measure: Insulate knee walls to } \\
\text { maximum structurally allowable. Seal applicable key junctures in } \\
\text { knee wall areas. }\end{array}$ \\
\hline $\begin{array}{l}\text { 5. Sidewall } \\
\text { Insulation }\end{array}$ & $\begin{array}{l}\text { Mandatory measure: Dense-pack wall cavities to R-13 or } \\
\text { maximum structurally allowable. }\end{array}$ \\
\hline 6. Floor Insulation & $\begin{array}{l}\text { Mandatory measure if there is an open foundation and no existing } \\
\text { insulation. } \\
\text { Recommended measure otherwise: Insulate floors that define } \\
\text { heating envelope to R-19 (if none existing). }\end{array}$ \\
\hline $\begin{array}{l}\text { 7. Heating System } \\
\text { Replacement }\end{array}$ & -case consideration. \\
\hline
\end{tabular}

Based on a literature search and private communications within ORNL and outside, similar field standards and evaluation studies of retrofit measures from multi-family, high-rise and commercial buildings are not currently available. There are, however, numerous case studies of single- and multi-family buildings as well as commercial and high-rise buildings.

In multi-family, commercial and high-rise buildings, the retrofit measures are primarily focused on HVAC, lighting and air tightness. A report by the Architecural and Engineering Services of Public Works Government Services Canada provides air-leakage control guidelines for high-rise office buildings to be used as a tool in the construction industry (18). A recent conference held in Chicago focused on the multi-family buildings and featured several case studies of energy efficiency and retrofit strategies (19).

Buildings with masonry walls present particular challenges to retrofitting through added insulation. Very often, there are aesthetic barriers to adding insulation on the outside. Adding insulation on the inside could result in moisture-related problems, especially in cold climates (20, 21). The use of semi-permeable foam insulation in contact with the back of the existing masonry 
is the most common successful strategy for interior insulation retrofits. The masonry retrofit report provides some guidelines to improve energy efficiency and durability of the buildings and reduce the likelihood of moisture related problems (20).

A brief review of selected case studies is provided in Appendix D. Building America (27), NYSERDA (28) and the California Energy Commission (29) are useful resources for further case studies of new and retrofit construction and building energy efficiency measures.

\section{FIRE SAFETY CODES}

In addition to energy efficiency, fire safety requirements are also part of the building codes. The main fire code followed in the U.S. is the International Fire Code (IFC) from the International Code Council, Inc. The current version of the code is the IFC 2009. Most states implement the IFC or a local code based on the IFC. Reed Construction Data (12) lists the statewise implementation of the fire codes across the U.S.

Based on specific conditions, states may enforce additional fire safety codes. An example is the Wildland-Urban Interface code in California (30), which pertains to buildings in wildfire prone regions.

ASTM International (31), National Fire Protection Association (NFPA) (32) and Underwriters Laboratories (UL) provide a host of test standards to characterize building materials and assemblies based on their flammability and ignition resistance characteristics. Following is a partial list of important and relevant test standards:

- ASTM C739/C1497: Standard Specification for Cellulosic Fiber Loose-Fill Thermal Insulation; this standard includes a method for testing the smoldering combustion characteristics of loose-fill insulation.

- ASTM D635: Standard Test Method for Rate of Burning and/or Extent and Time of Burning of Plastics in a Horizontal Position.

- ASTM E84 / UL 723: Standard Test Method for Surface Burning Characteristics of Building Materials.

- ASTM E1 19 / UL 263: Standard Test Methods for Fire Tests of Building Construction and Materials.

- ASTM E136: Standard Test Method for Behavior of Materials in a Vertical Tube Furnace at $750^{\circ} \mathrm{C}$.

- ASTM E648: Standard Test Method for Critical Radiant Flux of Floor-Covering Systems Using a Radiant Heat Energy Source.

- ASTM E970: Standard Test Method for Critical Radiant Flux of Exposed Attic Floor Insulation Using a Radiant Heat Energy Source.

- NFPA 268: Standard Test Method for Determining Ignitibility of Exterior Wall Assemblies Using a Radiant Heat Energy Source.

- NFPA 286 / UL 1715: Standard for Fire Test of Interior Finish Material (also known as the 'Room Corner Test').

ANSI/EIMA 99-1 uses the following test methods to evaluate EIFS fire performance relative to site-specific requirements. The EIFS reinforced coating system shall also have a flame spread of 25 or less, and smoke developed of 450 or less per ASTM E84. 
Table 15 EIFS System fire Performance Tests from ANSI/EIMA 99-A-2001

\begin{tabular}{|l|l|}
\hline Characteristic & Test Method \\
\hline Fire Endurance & ASTM E119 \\
\hline Full scale diversified fire test & Modified ASTM E108 \\
\hline Full scale multi-story fire test & UBC Standard 26-4 \\
\hline $\begin{array}{l}\text { Intemediate Scale Multi-Story } \\
\text { Fire Test }\end{array}$ & $\begin{array}{l}\text { ANSI/NFPA 285 (UBC } \\
\text { Standard 26-9) }\end{array}$ \\
\hline Radiant Heat Exposure & ANSI/NFPA 268 \\
\hline
\end{tabular}




\section{REFERENCES}

1. Residential Energy Consumption Survey, U.S. Energy Information Administration, http://www.eia.gov/consumption/residential/.

2. Commercial Buildings Energy Consumption Survey, U.S. Energy Information

Administration, http://www.eia.gov/emeu/cbecs/contents.html.

3. Annual Energy Outlook 2011, U.S. Energy Information Administration, http://www.eia.gov/forecasts/aeo/.

4. M. Evans, B. Shui and A. Delgado, 'Shaping the Energy Efficiency in New Buildings: A Comparison of Building Energy Codes in the Asia-Pacific Region', PNNL-122267, Pacific Northwest National Laboratory, September 2009.

5. M.A. Halverson, B. Shui and M. Evans, 'Country Report on Building Energy Codes in the United States', Pacific Northwest National Laboratory, April 2009.

6. B. Shui, M. Evans, H. Lin, W. Jiang, B. Liu, B. Song and S. Somasundaram, 'Country Report on Building Energy Codes in China', Pacific Northwest National Laboratory, April 2009.

7. D. Conover, R. Bartlett and M. Halverson, 'Comparison of Standard 90.1-07 and the 2009 IECC with Respect to Commercial Buildings', PNNL-19054, Pacific Northwest National Laboratory, December 2009.

8. U.S. DOE 2010 Building Energy Codes Annual Report, http://www.energycodes.gov/publications/general/BECP_FY10_AnnualReport.pdf

9. Buildings Energy Code Program, 'Impacts of Standard 90.1-2007 for Commercial Buildings at State Level', Pacific Northwest National Laboratory, September 2009.

10. Buildings Energy Code Program, 'Impacts of the 2009 IECC for Residential Buildings at State Level', Pacific Northwest National Laboratory, September 2009.

11. International Code Council, http://www.iccsafe.org/Store/Pages/Category.aspx?cat=ICCSafe\&category=1170\&parentcate gory=Store Products

12. Building Code Reference Library, Reed Construction Data, http://www.reedconstructiondata.com/building-codes/.

13. S. Bin, L. Haiyan, Y. Cong, M. Halverson, S. Bo,L. Jingru, M. Evans, Z. Xiaojiao and L. Siwei, 'Synthesis Report on the Implementation of Building Energy Codes in China', March 2011.

14. Building codes in Hong Kong and China: http://www.arch.hku.hk/research/beer/besc.htm\#China

15. Y.J. Huang, S. Lang, J. Hogan and H. Lin, 'An Energy Standard for Residential Buildings in South China', 2003, http://china.lbl.gov/publications/energy-standard-residential-buildingssouth-china.

16. U.S. Department of Energy Weatherization \& Intergovernmental Program, http://www1.eere.energy.gov/wip/index.html.

17. M. Schweitzer, Estimating the National Effects of the U.S. Department of Energy's Weatherization Assistance Program with State-Level Data: A Metaevaluation Using Studies From 1993 to 2005, ORNL/CON-493, September 2005.

18. Air Leakage Control: Retrofit Measures for High-Rise Office Buildings, A\&E Services Branch, Technology Sector, RD\&D Division, September 1993. 
19. Mutlifamily Buildings 2011, The Energy Efficiency Edge, http://www.cvent.com/events/multifamily-buildings-2011/event-summary796402cd1acc4bb59c5757a1dbf55017.aspx.

20. J. Straube and C. Schumacher, 'Interior Insulation Retrofits of Load-Bearing Masonry Walls in Cold Climates', Building Science Digest 114, March 2007.

21. Insulation Retrofits on Old Masonry Buildings - Building Science Podcast, Joe Lstiburek, http://www.greenbuildingadvisor.com/blogs/dept/building-science/insulation-retrofits-oldmasonry-buildings-building-science-podcast.

22. Comprehensive Energy Retrofit, Case Study: Joe Wesley Miller Companies, http://apps1.eere.energy.gov/buildings/publications/pdfs/building_america/ba_cs_retrofit_joh n wesley miller.pdf.

23. Monitoring the Performance of an EIFS Retrofit on a 15-Storey Apartment Building, Research Higlights Technical Series 01-104, www03.cmhcschl.gc. ca/?lang=en\&cat $=39 \&$ itm $=17$.

24. New Construction and Green Buildings Programs: Four Times Square, http://www.nyserda.org/programs/Green_Buildings/casestudies/4-times_square.pdf.

25. M.N.A. Said, R.G. Demers and L.L.McSheffrey, 'Hygrothermal Performance of a Masonry Wall Retrofitted with Interior Insulation,' NRCC-46109, September, 2003.

26. 'There are Holes in Our Walls,' A Report Prepared for Urban Green Council by Steven Winter Associates, April 2011.

27. Building America - Resources for Energy Efficient Homes, DOE Building Technologies Program, http://www1.eere.energy.gov/library/default.aspx?Page=2\&spid=2.

28. New York State Energy Research and Development Authority (NYSERDA), http://www.nyserda.org/programs/default.asp.

29. The California Energy Commission, http://www.energy.ca.gov/research/buildings/index.html.

30. California Department of Forestry and Fire Protection, Wildland Urban Building Codes, http://www.fire.ca.gov/fire_prevention/fire_prevention_wildland_codes.php.

31. ASTM International, Fire Standards and Flammability Standards, http://www.astm.org/Standards/fire-and-flammability-standards.html.

32. National Fire Protection Association, Codes \& Standards, http://www.nfpa.org/categoryList.asp? categoryID=124\&URL=Codes\&Standards.

33. UL Standards, http://www.ul.com/global/eng/pages/corporate/standards/.

34. International Energy Agency, Energy Technology Perspectives 2010, Scenarios and Strategies to 2050.

35. National Bureau of Statistics of China, China Statistical Yearbook 2003 (ISBN 7-5037-40604/C 2031)

36. National Bureau of Statistics of China, National Real Estate Development and Sales in 2011, January 19, 2012 


\section{APPENDIX A: NOMENCLATURE}

ANSI: $\quad$ American National Standards Institute

ASHRAE: American Society of Heating, Refrigerating and Air-Conditioning Engineers

ASTM: $\quad$ ASTM International, Inc., formerly American Society for Testing and Materials

BECP: $\quad$ Building Energy Codes Program of U.S. DOE

BS (BSI): British Standards Institute

CBECS : $\quad$ Commercial Buildings Energy Consumption Survey

CEN / CENELEC: Common European Organization for Standardization

CEN / TC 88: European Committee for Standardization - Technical Committee

CERC-BEE: Clean Energy Research Center - Building Energy Efficiency

DIN: $\quad$ German Standards Committee

DOE: $\quad$ Department of Energy (U.S.)

EIA : $\quad$ U.S. Energy Information Administration

EIFS: $\quad$ Exterior Insulation Finish Systems

EIMA: $\quad$ EIFS Industry Members Association

EN: $\quad$ European Norms (prEN indicates a draft standard)

EOTA: $\quad$ European Organisation for Technical Approvals

EPS: $\quad$ Expanded polystyrene

ETAG: $\quad$ European Technical Approval Guideline

ETICS: $\quad$ External thermal insulation composite systems

HDD: $\quad$ Heating Degree Days

ICBO: International Conference of Building Officials

ICC: International Code Council

ICC ES: International Code Council Evaluation Service

IECC : International Energy Conservation Code

IES: $\quad$ Illuminating Engineering Society of North America

MEC : $\quad$ Model Code for Energy Conservation

PB EIFS: $\quad$ Polymer Based EIFS (majority of EIFS in North America)

PIR: $\quad$ Polyisocyanurate insulation

PU: $\quad$ Polyurethane insulation

RECS : $\quad$ Residential Energy Consumption Survey

Rendering system: Reinforced base coat and finish coat(s)

UEAtc : $\quad$ European Agreement Union Technical Committee

U.S.: United States

XPS: $\quad$ Expanded polystyrene 


\section{APPENDIX B: CERC PROGRAM VISITOR REPORT, JUNE 6- 7, 2012}

Six visitors from China, listed in Table 16, visited Oak Ridge National Laboratory on June 6-June 7, 2012. As the attached agenda shows, we spent the first day visiting the Gate Precast Factory near Lexington, KY. Kai Wang of ORNL graciously served as interpreter for the trip. The Gate Precast facility maintains an open-door policy and works to educate architects and engineers about the characteristics of pre-cast construction. Mark Pedron (859-744-9481), the plant manager, delayed production so that we could watch the process, and gave us a detailed presentation about several of their recent installations. The production we observed was for an insulated pre-cast wall with an integral moisture barrier. They used a two-part form of their own design to enable them to place the insulation and moisture barrier in place, with a skirt of the moisture barrier extending out the sides of the wall section, before pouring the concrete for the interior face of the panel. See the photos that show both the production process and some examples of the sides of completed panels. The connectors used to anchor the front wall section to the rear wall section were made of a non-metallic composite to minimize the thermal short circuits through the two-inch thick polyiso insulation. Special tapes were used to seal off these penetrations to keep the moisture barrier continuous across the surface of the insulation.

On June 7, the visitors toured a number of ORNL facilities and met to discuss possible research activities for 2013. Kai Wang and Xiaobing Liu helped as interpreters during the day's meetings, which were also attended by Som Shrestha and Ron Ott. Heather Buckberry led the group on a tour of the wall section mock-up on the ORNL site that was prepared to show how the pre-cast wall sections are used here on several new ORNL buildings. Therese Stovall led the group through the ORNL building envelope laboratories.

After lunch, there were extensive discussions about closing out the Year 1 research activities and planning future research activities. Therese Stovall brought up the issue of standards harmonization, of particular interest to the US CERC industrial partners. Director Bo, who also leads the insulation standards activities in China, encouraged these companies to participate in the Chinese standards adoption activities. Two of the visitors represented China Industry Partners in the CERC program and were interested in possible joint research activities. These included improved phenolic insulation and the development of a pre-faced EIFS system that would avoid some of the fire problems that have occurred during China construction and retrofit activities. Song Bo suggested a symposium focused on wall insulation systems. Other potential future research activities discussed included:

- Test methods to determine the useful lifetime of EIFS

- Developing work practices with improved safety allowances (or sharing U.S. practices)

- Compare US and China test practices, methodology and results, relevant to wall insulation

- Development of a pre-faced EIFS system that could be mass produced

- Improved wall insulation system for retrofits, along with improved evaluation processes To close out the day, Bill Miller led the group on a tour of the ZEBRA houses. The visitors were especially interested in the instrumentation used to collect energy use and load information and in the Exterior Insulation Finish System (EIFS) house. 
Table 16 Visitor List

\begin{tabular}{|l|l|l|}
\hline Song Bo & $\begin{array}{l}\text { Director, China Academy of Building } \\
\text { Research }\end{array}$ & songbo163163@163.com \\
\hline Wang Xinmin & $\begin{array}{l}\text { Manager, Beijing Gold Coast Science } \\
\text { and Technology Development Company }\end{array}$ & wxmsys@sina.com \\
\hline Zhang Sisi (Sissi) & $\begin{array}{l}\text { Engineer, China Academy of Building } \\
\text { Research }\end{array}$ & sisi_zh@163.com \\
\hline Sun Chuihai & $\begin{array}{l}\text { General Manager, Beijing Lions Hi-tech } \\
\text { Co., Ltd }\end{array}$ & \\
\hline Lu Dapeng (Lewis) & $\begin{array}{l}\text { Technical Director and Deputy General } \\
\text { Manager, Wattens(Beijing) Coating and } \\
\text { Insulation Co., Ltd }\end{array}$ & 1ewislv@sohu.com \\
\hline Zhang Lixia (Selina) & $\begin{array}{l}\text { Technology Engineer, Jilin Kelong } \\
\text { Building Energy-saving Technology } \\
\text { Co., Ltd. }\end{array}$ & 94407893@qq.com \\
\hline
\end{tabular}

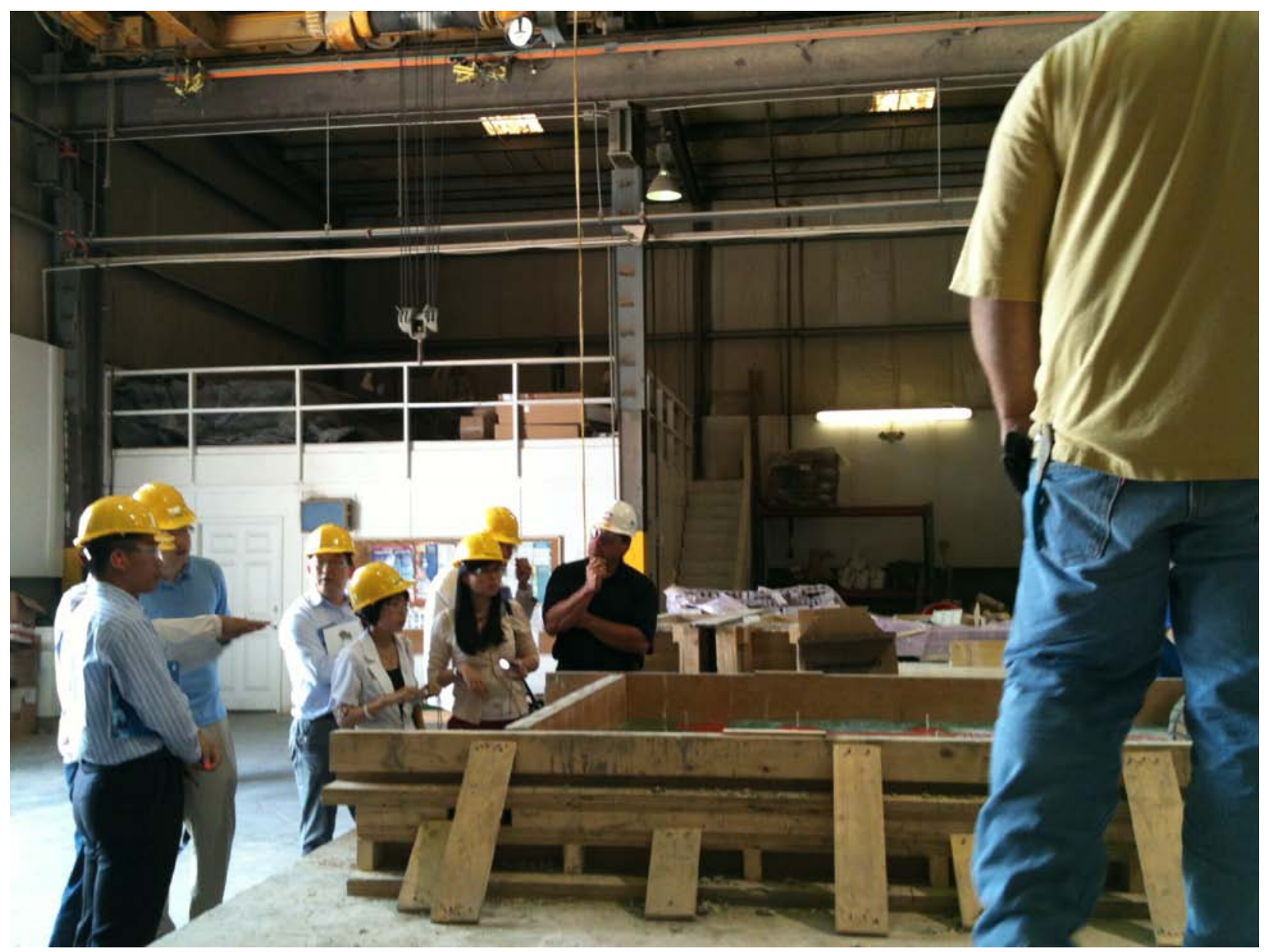

Figure 5 Viewing precast process, visible are green moisture barrier placed on top of PIR panels, connection pins, and red tape to complete the moisture barrier at these penetrations 


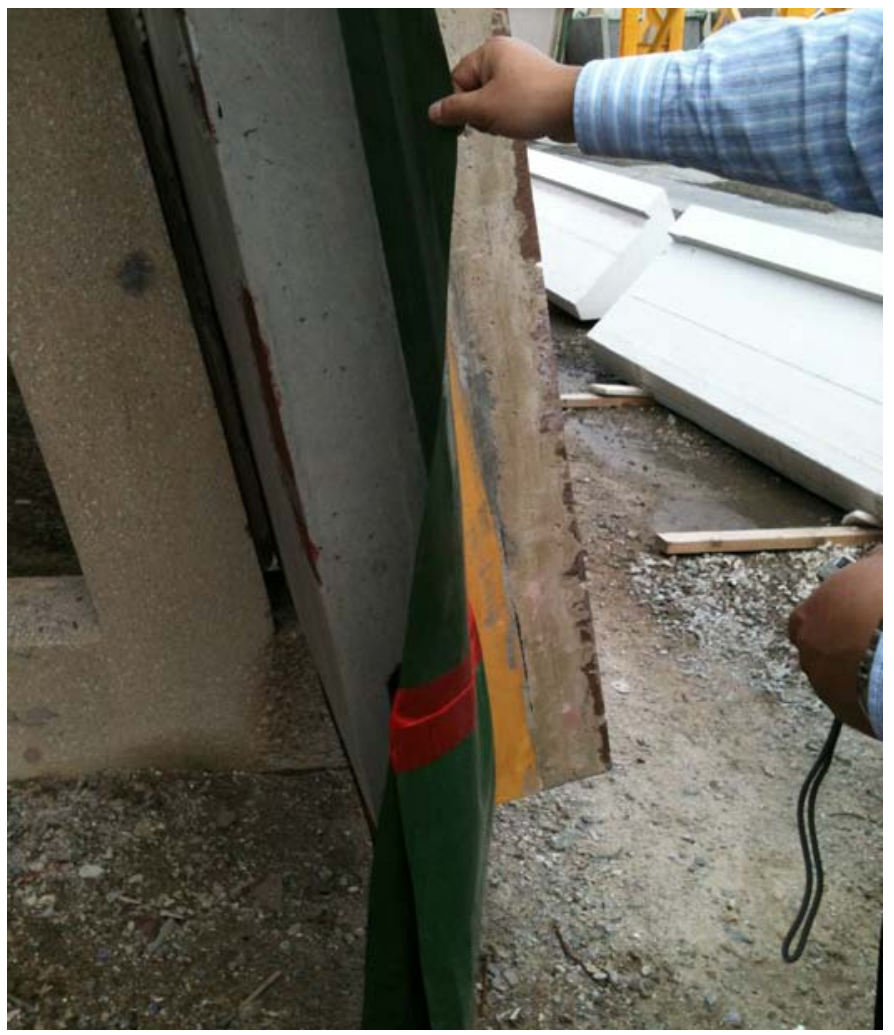

Figure 6 Cross section of insulated precast wall with integrated moisture barrier. Finished surface to the right, yellow side of polyiso layer partially visible, green moisture barrier (with red taped seam) extending out side of wall section, and plain concrete side of wall on the left 


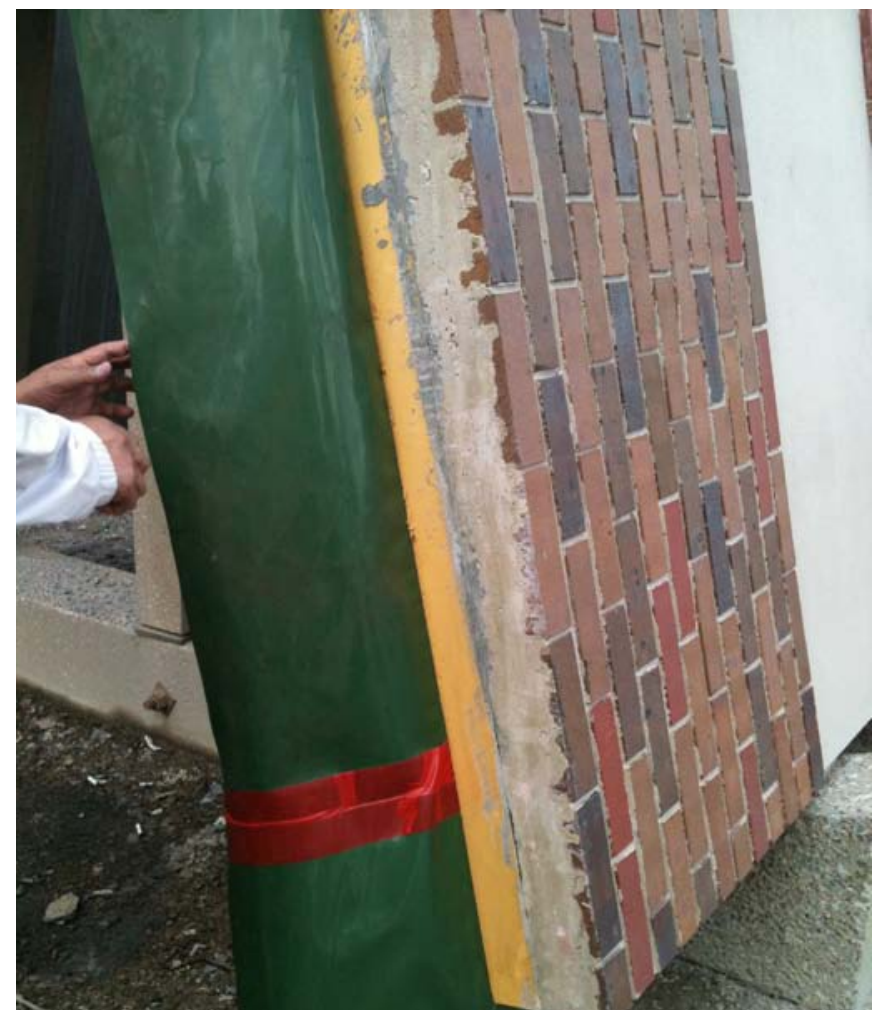

Figure 7 Same wall section but picture taken to show the finished front surface, then the polyiso and moisture barrier

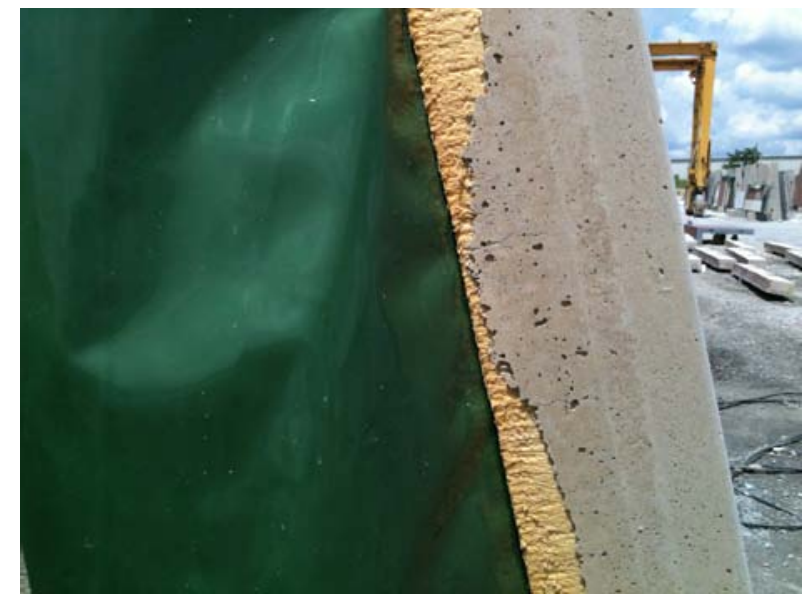

Figure 8 Close up view of side of wall section 


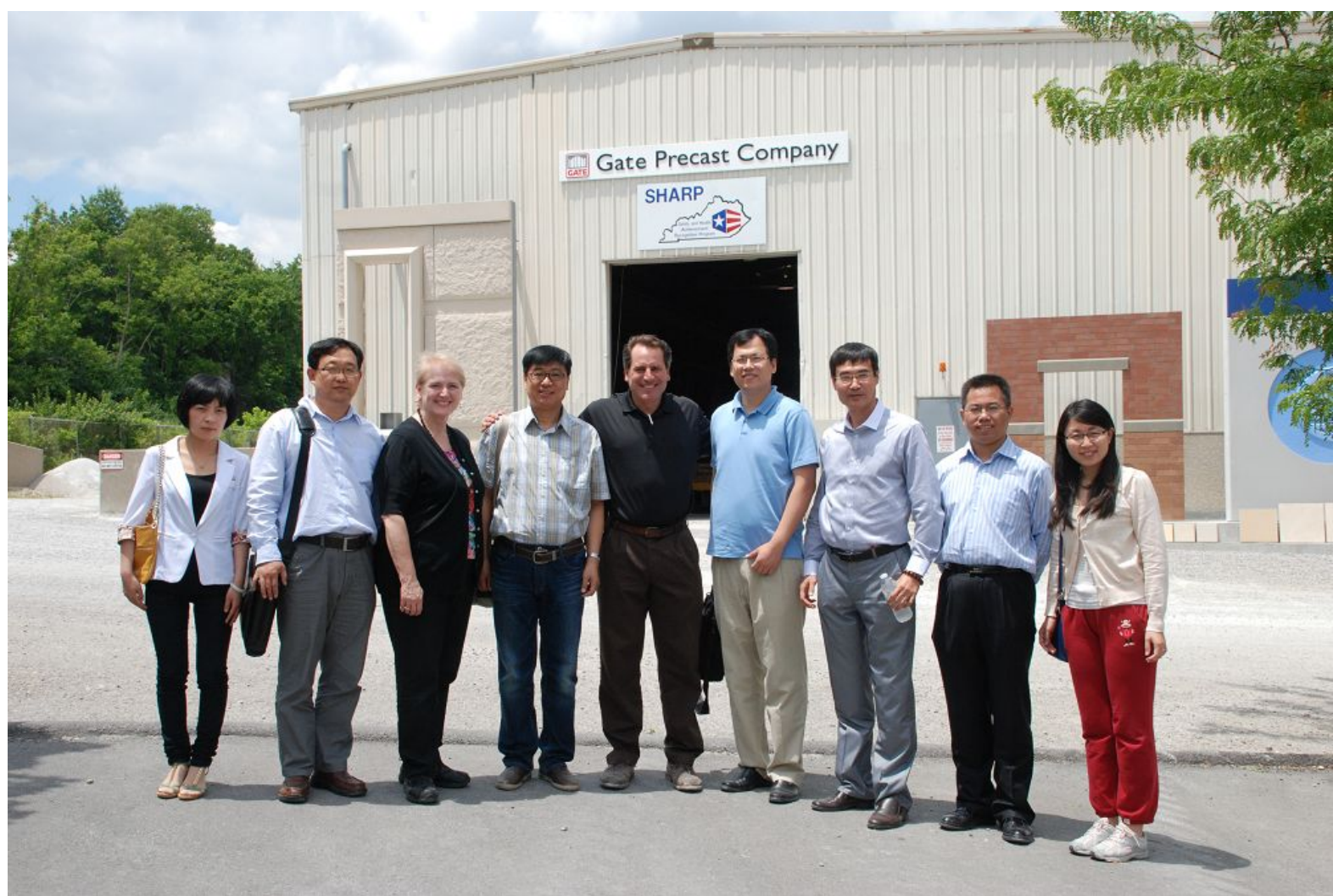

Figure 9 Tour group at Gate Precast Company facility in Lexington , KY 
CERC/ORNL Agenda

Oak Ridge National Laboratory

Building 3147, Room 130

June 6, 2012

\begin{tabular}{|l|l|}
\hline Time & Principal Investigator/Presentation \\
\hline $7: 45 \mathrm{am}$ & Depart Crown Plaza Hotel \\
\hline $11: 00 \mathrm{am}$ & Arrive Gate Precast Facility \\
\hline $1: 00 \mathrm{pm}$ & Depart Gate Precast \\
\hline $5: 00 \mathrm{pm}$ & Arrive back in Knoxville \\
\hline & \\
\hline
\end{tabular}

June 7, 2012

\begin{tabular}{|c|l|}
\hline $8: 00 \mathrm{am}$ & Depart Crown Plaza Hotel \\
\hline $8: 45 \mathrm{am}$ & Arrive Oak Ridge National Laboratory Visitor Center \\
\hline $9: 00 \mathrm{am}$ & Greeting from Ronald Ott, Assistant Division Director \\
\hline $9: 30 \mathrm{am}$ & $\begin{array}{c}\text { Overview of ORNL's Building Technologies Research and Integration } \\
\text { Center, Therese Stovall }\end{array}$ \\
\hline $10: 00 \mathrm{am}$ & $\begin{array}{c}\text { Tour laboratories and demonstration wall section, Therese Stovall and } \\
\text { Heather Buckberry }\end{array}$ \\
\hline $12: 00 \mathrm{pm}$ & Working lunch - discuss CERC work in Year 3 \\
\hline $2: 00 \mathrm{pm}$ & Depart ORNL to tour Zebra houses \\
\hline $4: 45 \mathrm{pm}$ & Depart for airport \\
\hline $5: 20 \mathrm{pm}$ & Arrive airport \\
\hline $6: 50 \mathrm{pm}$ & Flight departure \\
\hline
\end{tabular}

\begin{tabular}{|l|l|}
\hline Chinese Visitors & ORNL Attendees \\
\hline Song Bo & Therese Stovall \\
\hline Wang Xinmin & Xiaobing Liu \\
\hline Zhang Sisi & Ronald Ott \\
\hline Sun Chuihai & William Miller \\
\hline Lu Dapeng & Kai Wang \\
\hline Zhang Lixia & Heather Buckberry \\
\hline
\end{tabular}




\section{APPENDIX C: COMMONLY USED MATERIALS IN CHINESE EXTERNAL WALL INSULATION}

Molded polystyrene foam (EPS) board is a molding made of expandable polystyrene beads by heating pre-expansion in the mold, producing a closed-cell structure which should not be exposed to temperatures above $75^{\circ} \mathrm{C}$. The molded polystyrene foam board is composed of a number of closed polyhedral cells. The cellular composition has a cell size of 0.2 to $0.5 \mathrm{~mm}$ in diameter and a honeycomb wall thickness of $0.001 \mathrm{~mm}$. The polystyrene makes up only about $2 \%$ of the volume, the rest is air. The still air within the honeycomb is a poor conductor of heat, and therefore this material has good thermal insulation properties. Coupled with its unique antivapor permeability, high compressive strength, easy installation and construction for long service life, which are important to building energy-saving insulation materials, this product has been widely used in construction, packaging and engineering.

Extruded polystyrene foam (XPS): The production process of XPS involves molten polystyrene resins and additives, including foaming agents, expanded in a uniform speed through extrusion pressure roller systems. A vacuum forming zone is used in some cooling processes. The XPS production is a continuous extrusion that forms the product structure in one step, rather than by the compression molding after the expansion of the polystyrene particles used to make EPS. The XPS has a very complete closed - cell structure, there are no gaps between the cells. XPS board has long-lasting insulation properties, excellent moisture resistance and anti-vapor permeability and high compressive strength.

Rigid polyurethane foam (PUR) is an elastomeric material formed by the reaction of the isocyanate component (referred to as group A) and resin group (referred to as the R group). Group A can be monomer or polymer, isocyanate derivatives, prepolymers and semiprepolymers; and end products of the polyol and isocyanate reaction system. The $\mathrm{R}$ group must be composed by the terminal hydroxyl resin and hydroxy terminated chain extenders must contain terminal hydroxyl resin, used to improve the reactivity of the catalyst. Rigid polyurethane foam (PUR) is a closed cell structure, with effective insulation, low density, compression strength, and easy construction qualities. It also has good noise and shock performance, electrical insulation, high temperature resistance, good chemical stability, resistance to many solvents and oils and so on.

Plastic powder EPS granules in an insulation mortar slurry: The EPS granules are pre-mixed with dry mortar. The mortar forms the main cementitious material. Fibrous additives are used to obtain the appropriate crack resistance. The slurry formed by the addition of water to the EPS granules-mortar mixture produces a lightweight aggregate. The proportions of the components are varied to obtain a uniform mixture on site. The result has a lower thermal conductivity than regular mortar, but still a much higher thermal conductivity than other insulating materials. This system has high water resistance, low shrinkage, is fast drying, easy construction, good thixotropy, holistic, seamless, has a high fire rating, and good durability characteristics. It has been widely used in energy efficient buildings but is less used today. 


\section{APPENDIX D: U.S. RETROFIT CASE STUDIES}

2000-Square-Foot Adobe Residential Structure: This adobe (masonry) structure was located in Tucson, AZ (climate zone 2). Foam insulation was applied to the exterior of the walls and roof. The walls were finished with stucco and the roof insulation was covered with a reflective built-up roof. These and other retrofit measures resulted in $75 \%$ lower heating and cooling cost from pre-retrofit conditions (20).

EIFS Retrofit on a 15-Storey Apartment Building: The rehabilitation plan of a 15storey, 112-unit cooperative housing in Toronto, Canada included replacement of windows and doors and installation of an exterior insulation finish system (EIFS). The EIFS maintained the original masonry in a warm and stable environment and provided effective control of heat transfer, air leakage, vapor diffusion and rain penetration (23). However, some moisture penetration of the exterior finish was observed, though due to the limited amount of data, it was not possible with any degree of certainty to determine the source of the moisture, although vapor penetration was suspected. It was also noted that long-term monitoring was required to determine the performance of the retrofitted wall over time.

Four Times Square, New York: This is a 1.6 million square feet office complex that was retrofitted. The energy efficiency measures included fuel cells, waste heat recovery, high performance window glazing, photovoltaics, energy-efficient lighting, occupancy sensors, etc. The resulting annual energy cost savings was $\$ 1,760,000$, annual energy use savings was 20,841,269 kWh/year and carbon dioxide emissions reduction was 9,191 tons per year (24).

Masonry Wall Retrofitted with Interior Insulation: A 4-storey masonry building in eastern Canada was retrofitted and converted to offices. The wall retrofit included the addition of fiberglass batt insulation and vapor and air barriers on the inside of the brick wall. The $\mathrm{R}_{\mathrm{SI}^{-}}-3.5\left(\sim \mathrm{R}_{\mathrm{US}^{-}}\right.$ 19) fiberglass insulation was installed with steel stud framing on the wall interior (25).

A section of the retrofitted wall was continuously monitored for over two years. The retrofit had a negligible effect on the drying potential of the brick wall during the summer months but reduced the wall drying potential during the winter months. The moisture level in the brick wall increased, which was partially due to the retrofit and partially due to a wetter weather during the monitoring period, and it was noted that the brick wall may be at a higher risk of frost damage than before the retrofit.

Impact of Room Air-Conditioners on Building Envelope: This study examined the impact on thermal performance of building envelope penetrations associated with distributed heating, ventilating, and air conditioning (HVAC) equipment such as window air conditioners (ACs), sleeved ACs, and packaged terminal air conditioners and heat pumps (PTACs and PTHPs) (26). This was not focused on a single building retrofit, but is relevant due to its impact in retrofit and replacement situations. The study was conducted in multi-family buildings in New York City, with an estimated 13.3 million rooms. Room air conditioners pose two main problems for the building envelope:

- Air leakage pathways increasing the uncontrolled movement of air through buildings (infiltration).

- Thermal bridging and the resulting increased heat flow through the components. 
The study found the primary cause of the leakage to be a lack of long-term integrity in the installation kits for window ACs and poor fit and sealing for sleeved units and PTACs. Assuming $30 \%$ of rooms to be cooled, it would mean about 4 million punctures in building envelopes. The associated heating losses are estimated to cost in the neighborhood of $\$ 150$ million per year in excess fuel use, and result in the emission of around 400,000 tons of Carbon Dioxide annually - about $1 \%$ of the city's annual total. The study also evaluated a variety of offthe-shelf products and alternative technologies that can reduce infiltration and thermal losses. 